\title{
ReCOMmendations for the prevention, diagnosis and treat- ment of infLUenza in adults for Primary care physiciAnS: FLU COMPAS PCP - ADULTS
}

Expert recommendations from the Polish Society of Family Medicine, Polish Vaccinology Society and from the Polish National Program against Influenza

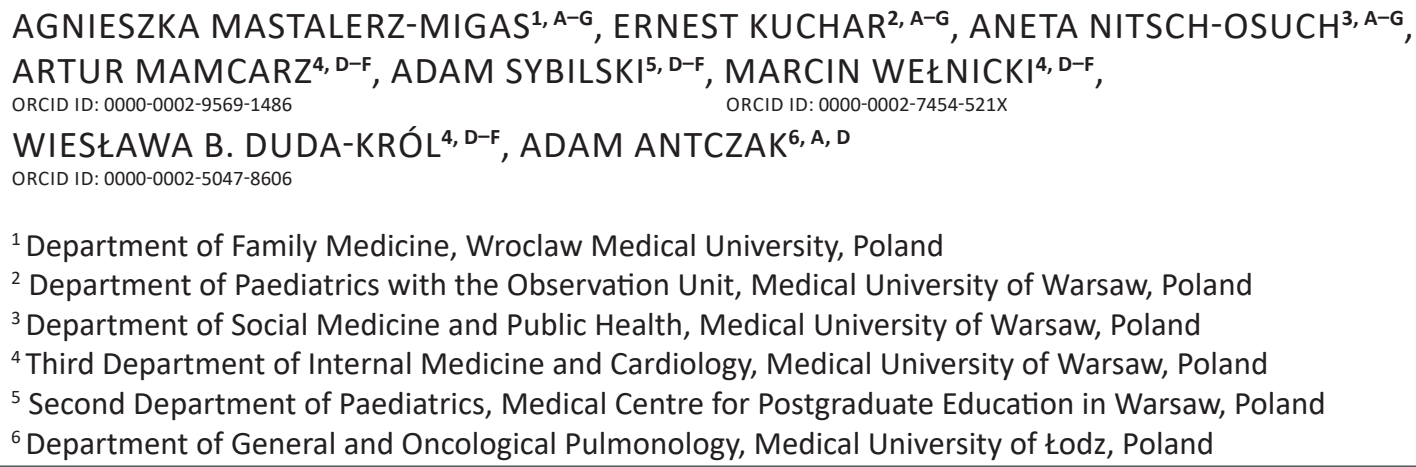

A - Study Design, B - Data Collection, C - Statistical Analysis, D - Data Interpretation, E - Manuscript Preparation, F - Literature Search, G - Funds Collection

Summary Influenza is an acute infectious disease of viral etiology which, unlike the common cold, can lead to serious complications such as pneumonia, myocarditis, inflammation of the kidneys, nervous system, and muscles, and even death. Vaccination is the most effective method of preventing influenza and should be recommended to everyone over six months of age, with particular emphasis on risk groups. When the symptoms of influenza occur, the only drugs recommended for curative treatment are neuraminidase inhibitors (of which only oseltamivir is available in Poland). Influenza diagnosis of should be made during the epidemic season based on clinical signs. Only curative treatment should be employed in risk groups. Treatment should not be delayed in order to wait for the results of tests confirming infection.

Key words: influenza, human, vaccination.

Mastalerz-Migas A, Kuchar E, Nitsch-Osuch A, Mamcarz A, Sybilski A, Wełnicki M, Duda-Król WB, Antczak A. Recommendations for the prevention, diagnosis and treatment of influenza in adults for primary care physicians: FLU COMPAS PCP - ADULTS. Fam Med Prim Care Rev 2020; 22(1): 81-96, doi: https://doi.org/10.5114/fmpcr.2020.90629.

Influenza is an acute infectious disease. It is caused by the influenza virus, which mainly affects the respiratory tract, but in complicated cases it can also affect other organs (including the myocardium, kidneys, skeletal muscles and neurons). The influenza virus is an RNA virus from the Orthomyxoviridae family, containing type $A$, type $B$ and type $C$ viruses, but only $A$ and $B$ can cause the disease in humans.

Influenza viruses are highly variable. Antigenic changes can be caused by antigenic drift, i.e. by spontaneous point mutations that are responsible for the ongoing variability of influenza viruses, or an antigenic shift (viral reassortment), which occurs only in the influenza A virus. Viruses arising as a result of antigenic shift may cause pandemics, which happens every 10-40 years. The antigenic shift involves the replacement of a whole
RNA segment of the virus or even several segments, provided that a single cell is infected by two different subtypes of the virus simultaneously [1].

\section{Epidemiology of influenza}

The World Health Organization (WHO) estimated the annual global attack rate of influenza at $5-10 \%$ in adults and $20-30 \%$ in children. Each year there are 3 to 5 million cases of severe illness and up to 500,000 deaths from influenza [2]. Data on influenza and influenza-like illness, hospitalizations and deaths from influenza in subsequent seasons in Poland (2013-2019) are presented in Table 1.

Table 1. Influenza and influenza-like illness, hospitalizations and deaths from influenza in subsequent seasons, 2013-2019 (data from

\begin{tabular}{|c|c|c|c|c|c|c|}
\hline Season & $2013 / 2014$ & $2014 / 2015$ & $2015 / 2016$ & $2016 / 2017$ & $2017 / 2018$ & $2018 / 2019$ \\
\hline Number of cases & 2095434 & 2986919 & 3289235 & 3964655 & 4585448 & 3805280 \\
\hline Change & & $42.5 \%$ & $10.1 \%$ & $20.3 \%$ & $15.7 \%$ & $-17 \%$ \\
\hline Hospitalizations & 7311 & 9555 & 14113 & 14271 & 16411 & 15291 \\
\hline Change & & $30.7 \%$ & $47.7 \%$ & $1 \%$ & $15 \%$ & $-6.8 \%$ \\
\hline Deaths & 14 & 11 & 133 & 25 & 43 & 146 \\
\hline
\end{tabular}


As can be seen in the table above, about 3-4.5 million cases of influenza and influenza-like illness are recorded in Poland every year. Epidemiological data are published weekly by the National Institute of Public Health - National Institute of Hygiene (NIZP-PZH), and come from reports submitted by primary healthcare centres.

In the epidemic season, institutions providing outpatient healthcare services are obliged to prepare reports (weekly reports, or daily reports in the period of a significant increase in the incidence of disease) using the MZ-55 form. This form, in accordance with the definition adopted for the purposes of surveillance of infectious diseases in European Union member states (Journal of Laws L 159 of 18.06.2008, page 46) serves for reporting influenza (diagnosed based on clinical symptoms and/ /or laboratory tests) and all diagnosed cases of influenza-like illness and acute respiratory tract infections meeting the criteria listed in the form. The MZ-55 form is available on the websites of local sanitary and epidemiological stations, or can be generated directly from the IT system at the outpatient clinic.

Diagnosed cases of influenza also have to be reported pursuant to the Act of 5 December 2008 on the prevention and control of infections and infectious diseases in humans (Journal of Laws of 2018, item 151, 1669) on a relevant form for reporting infectious diseases (ZLK-1). Although information on the form clearly indicates that the diagnosis may be based on clinical symptoms or laboratory tests, in practice this form is only used to report cases of influenza confirmed by laboratory tests.

The correct reporting of all cases of influenza by all healthcare institutions is crucial so that epidemiological data gathered by institutions appointed for this purpose (NIZP-PZH) reflect the actual situation.

\section{Infection, clinical symptoms, complications}

The influenza virus is transmitted:

- by the droplet route, by aspirating the secretions of the respiratory tract of infected people, spreading the aerosol when coughing, sneezing or speaking;

- $\quad$ through direct contact with infected people or objects (door handles, handrails, etc.) contaminated with infectious secretions.

The incubation period from infection to the onset of symptoms is usually very short, 1-2 days (maximum 7). Patients are infectious for about 6 days, from the day before clinical symptoms begin to about 5 days after the onset of symptoms.

Uncomplicated influenza lasts about 3-7 days, and then the symptoms subside slowly. In general, full recovery takes a few weeks, and during that period a dry cough, weakness and increased fatigue may persist. Some infected patients may have emergency warning signs, suggesting worsening and severe influenza. These include:

- $\quad$ very high fever (over $40^{\circ} \mathrm{C}$ ),

- $\quad$ high fever persistent for more than 3 days,

- shallow breathing,

- dyspnoea,

- blood in sputum,

- severe weakness,

- muscle weakness,

- problems with moving limbs and walking,

- dizziness,

- dehydration (manifested, for example, by oliguria),

- disorders of consciousness.

Outpatients presenting with these symptoms have to be promptly referred to the hospital [4].

Influenza is a much more serious infection than other viral respiratory infections because of the risk of complications. People at high risk for influenza complications include [5]:

- children younger than 5 years (but especially those younger than 2 years),
- adults 65 years and older, but adults age 50 years and older are also at high risk,

- patients with chronic respiratory diseases (asthma, COPD), cardiovascular diseases, kidney disorders, liver disorders, diabetes, blood disorders, neurologic conditions, metabolic disorders, other health problems,

- $\quad$ pregnant women and women during the postpartum period (especially those up to 2 weeks after the end of pregnancy),

- $\quad$ people with a weakened immune system, including those infected with HIV, people younger than 19 years of age on long-term aspirin- or salicylate-containing medications, people with obesity (BMI higher than 40).

Possible complications of influenza include [4]:

- $\quad$ pneumonia (often severe, resulting from either influenza virus infection alone or from coinfection of flu virus and bacteria),

- $\quad$ upper respiratory tract infections (sinusitis, pharyngitis, laryngitis, tracheitis, bronchitis),

- myocarditis,

- myositis,

- nephritis,

- neurological complications (meningitis and encephalitis, peripheral neuritis, Guillain-Barré syndrome),

- exacerbation of chronic diseases (asthma, ischaemic heart disease, diabetes),

- death (due to influenza complications or exacerbation of the underlying disease).

\section{Risk groups for severe influenza and development of influenza complications}

\section{Patients with cardiovascular diseases}

Cardiovascular complications of influenza can be considered in two categories. First of all, influenza is a risk factor for the exacerbation of pre-existing cardiovascular diseases. Infection with the influenza virus can also cause cardiovascular complications in patients without pre-existing cardiovascular disease.

Influenza infection in patients with pre-existing cardiovascular disease

The relationship between the increased incidence of influenza and cardiovascular events was observed in the middle of the $20^{\text {th }}$ century. In Poland, the first reports on this relationship were presented by Edward and Andrzej Szczeklik. In the monograph Zawat serca [Myocardial infarction] these eminent Polish physicians wrote that they noticed a higher number of cases of myocardial infarction during periods of increased incidence of influenza. In 2003 Naghavi et al. demonstrated that the influenza virus has a destabilizing effect on atherosclerotic plaques in mice [6]. In 1994, Pleskov et al. suggested, however, that a history of influenza may not only be associated with an increased risk of a coronary event at a certain point of time, but also have a negative effect on the overall cardiovascular risk. They suggested that haemagglutinin may competitively bind to apolipoprotein B and low density lipoprotein receptor (LDLR), thereby reducing plasma clearance of $L D L$ molecules and stimulating the development of hypercholesterolemia, one of the major cardiovascular risk factors [7].

Regardless of the particulars of the pathophysiological mechanism, influenza has a significant effect on the clinical status of patients with cardiovascular disease, especially those with chronic coronary syndromes and chronic heart failure. Stewart et al. reported that the number of hospitalizations related to heart failure in December was $12 \%$ higher in women and $6 \%$ higher in men compared to the annual average. In July, the respective number of hospitalization was $7 \%$ and $8 \%$ lower than average. In patients aged over 75 years the peak winter rates of 
hospitalization were $15 \%$ to $18 \%$ higher than average for women and men, respectively. The researchers also found a correlation between the peak of the influenza season and mortality in the analysed patients - in December mortality in those aged over 75 years was $23 \%$ higher than average in women and $35 \%$ higher in men [8].

An increased number of hospitalizations related to heart failure (HF) has also been analysed in other studies, but increased mortality has not always been observed. A retrospective cohort study by Sandoval et al., who analysed influenza surveillance data from the United States, revealed an $11 \%$ higher hospitalization rate for patients with congestive heart failure during an influenza season [9]. On the other hand, Madjid et al. observed a clear increase in the incidence of acute myocardial infarction (AMI) and chronic ischaemic heart disease (ICH) coinciding with influenza epidemics compared to off-season weeks. The influenza season was associated with a $30 \%$ higher risk of acute myocardial infarction ( $\mathrm{HR} 1.3 ; 95 \% \mathrm{Cl}$ : 1.08-1.56), and a $10 \%$ higher risk of chronic ischaemic heart disease (HR 1.1; 95\% Cl: 0.97-1.26) [10].

In 2015 a meta-analysis of case-control studies on acute myocardial infarction and influenza was published by Barnes et al. This meta-analysis included 8 studies on influenza vaccination and 10 on influenza infection and AMI. Barnes et al. reported that recent influenza infection was associated with a two-fold higher risk of AMI (OR 2.01; 95\% Cl: 1.47-2.76), while influenza vaccination reduced the risk of AMI by about 30\% (OR 0.71; $95 \%$ Cl: 0.56-0.91) [11]. Interestingly, the range of efficacy of the influenza vaccine is comparable to that of many accepted coronary prevention measures such as smoking cessation (32-43\%), statins (19-30\%) and antihypertensive therapy (17-25\%) [12]. Therefore, it is not surprising that the guidelines of international societies of cardiology emphasize the growing importance of influenza vaccination. According to the 2016 European Guidelines on cardiovascular disease prevention, in clinical practice annual influenza vaccination may be considered in patients with established cardiovascular disease (class of recommendations IIb, level C), and according to the 2019 ESC guidelines for the diagnosis and management of chronic coronary syndromes, annual influenza vaccination is strongly recommended (class of recommendation I, level B). Recommendations indicate that an annual influenza vaccination can improve prevention of acute myocardial infarction in patients with chronic coronary syndromes, improve the prognosis in patients with heart failure, and decrease cardiovascular mortality in adults aged over 65 years $[13,14]$.

Of note is that influenza not only increases the risk of cardiovascular events, but also worsens the prognosis of patients with acute myocardial infarction. Vejpongsa et al. analysed over 1.8 million admissions for acute myocardial infarction in 2013-2014, and found that influenza and other respiratory viral infections were diagnosed in about $1.1 \%$ of patients. Acute myocardial infarction patients with concomitant influenza infection were hospitalized for a longer time, had a higher risk of development of shock, acute respiratory failure and acute kidney injury, and a higher rate of blood transfusion, but most importantly had a worse outcome than those with acute myocardial infarction alone, in terms of the in-hospital case fatality rate [15]. Another study, by Christiansen et al., demonstrated that influenza vaccination was associated with a significant $8 \%$ decrease in one-year mortality in patients previously hospitalized at intensive care units (HR 0.92; 95\% Cl: 0.89-0.95), a decreased risk of stroke (HR $0.84 ; 95 \% \mathrm{Cl}: 0.78-0.92$ ), but only a small, non-significant decrease in the risk of myocardial infarction [16]. These are only selected clinical data regarding the importance of influenza infection in patients with cardiovascular disease. In Poland, the association between seasonal influenza vaccination and reduced cardiovascular risk was discussed for the first time in 2007 (Podolec and Kopeć at the Polish Forum for the Prevention of Cardiovascular Diseases [17]). Since that time, the recommendation for routine influenza vaccination in all patients with chronic cardiovascular disease has become a strategy consistent with Evidence Based Medicine (EBM). Today, unjustified exemptions from influenza vaccination in patients with cardiovascular disease, especially those over 65 years of age, are regarded almost as a medical error.

\section{Cardiovascular complications of influenza infection in pa-} tients without pre-existing cardiovascular disease

Influenza infection also increases the risk of a cardiovascular event in patients without an established cardiovascular disease. It should be kept in mind that acute coronary syndrome is often the first sign of cardiovascular disease in people who thought they were in good health.

The influenza virus can also cause cardiovascular complications in people without any pre-existing cardiovascular disease, including young adults. It is believed that the influenza virus replicates in the cardiomyocytes of up to $10 \%$ of people with influenza. Therefore, it should be kept in mind that myocarditis (often with concomitant pericardial myositis) is a potential complication of influenza.

Diagnosis of myocarditis is not easy, but clinically it should be suspected in patients who, after a temporary improvement (4-7 days), have deteriorated tolerance to exercise with concomitant tachycardia inadequate to increasing body temperature. These patients may report unusual chest pain, and X-ray may reveal cardiomegaly, and cardiac troponins are often detected in blood. It was suggested that severe muscular ailments correlate with the risk of myocarditis; it is also possible that the prolongation of the QRS complex and depressed left ventricular function on admission to the hospital are negative predictive signs of myocarditis [18]. More recent studies indicate that the transient depression of myocardial function in patients with influenza infection detected by echocardiographic tissue imaging may occur more frequently than previously thought, and may not necessarily increase the risk of myocarditis. This study by Ito et al. [19] concerned, however, a small population of patients without elevated blood markers of myocardial injury.

In conclusion, the cardiovascular complications of influenza infection can be serious both in patients who were previously completely healthy (myocarditis) and in those with pre-existing cardiovascular diseases (myocardial infarction, stroke, acute heart failure, increased risk of death).

Data gathered so far from studies fully justify seasonal influenza vaccination as an effective secondary and primary measure preventing cardiovascular events.

From a cardiological point of view, the benefits of seasonal influenza vaccination are far greater than just "preventing" the infection alone.

\section{Patients with respiratory diseases}

It has been estimated that influenza infection causes a worsening in about $25 \%$ of patients with chronic lung diseases. These patients often require hospitalization and are characterized by high mortality (up to 30\%). Primary respiratory viral infection increases the risk of exacerbations in COPD and asthma. In the course of influenza virus infection, the respiratory epithelium necrotizes and exfoliates, uncovering the deeper layers of the basal membrane, thereby promoting bacterial adhesion and invasion $[20,21]$. Influenza infection is particularly dangerous in patients with COPD older than 75 years, those on home oxygen therapy, and those with cardiovascular diseases [22]. The original version of recommendations for influenza vaccination in COPD patients relied on a Cochrane database systematic review, which indicated a reduced incidence of exacerbations of COPD, especially 3 or more weeks after vaccination [23]. Further studies showed a $38 \%$ reduction in influenza-related hospitalizations among vaccinated vs unvaccinated patients [22]. Another study suggested that patients with COPD may also benefit from a regular influenza vaccination since it reduces the risk of ischaemic heart disease [24]. 


\section{Patients with diabetes mellitus}

The International Diabetes Federation reported that in 2017 there were 425 million people with diabetes around the world, including 327 million aged 20-64 years and 98 million aged 65-79 years. Diabetes and its complications caused 4 million deaths. The World Health Organization (WHO) forecasted that by 2030 diabetes will be one of the most common causes of death in the world [25].

Diabetes is associated with a number of immune disorders that promote an increased incidence of infectious diseases, have a negative effect on their clinical presentation, and increase the risk of hospitalization and mortality. On the other hand, people with infection may develop hyperglycaemia and insulin resistance, which complicates the infectious disease alone, but may also lead to acute diabetes complications, such as ketoacidosis or hyperglycaemic-hyperosmolar syndrome. Of note, the mortality rate in patients with infection and ketoacidosis is higher than $40 \%$. Moreover, patients with chronic diseases, including diabetes, are at risk of contracting an infectious disease when visiting healthcare facilities $[26,27]$.

Influenza is among the most common human respiratory infections. In patients with diabetes, recovery from influenza takes longer than in the general population, and these patients are at higher risk of influenza-related complications, usually pneumonia, bronchitis, sinusitis, otitis, more severe disease, greater risk of hospitalization, mortality and uncontrolled diabetes. Elderly patients are a special group of concern, because older age alone is a risk factor, and these patients also have multiple comorbidities, with cardiovascular diseases being the most frequent. Influenza morbidity and mortality are often affected by factors other than comorbidities $[28,29]$. For example, Alling et al. observed that in some periods higher mortality coincided with an epidemic of influenza, which was partly attributable to antigenic variation of viruses, for example the emergence of a new antigenic subtype or variants formed during antigenic shift [30].

Retrospective and observational studies as well as meta-analyses have revealed that patients with diabetes and influenza infection are 6 times more likely to be hospitalized and have a 3-fold higher risk of dying from pneumonia or influenza. It has also been estimated that patients with diabetes are 6 times more likely to die due to influenza-related complications $[5,26]$. A retrospective study using data from the surveillance of pandemic influenza in Montreal, Canada, in 2009 revealed that diabetes triples the risk of hospitalization after influenza $\mathrm{A}(\mathrm{H} 1 \mathrm{~N} 1)$ and quadruples the risk of admission at intensive care units once hospitalized [31]. Another study demonstrated that influenza vaccination, apart from reducing the risk of influenza and its complications, was associated with lower hospital admission rates: $15 \%$ for pneumonia or influenza, $19 \%$ for acute myocardial infarction, $22 \%$ for heart failure and $30 \%$ for stroke. The study also revealed a $24 \%$ lower all-cause mortality in vaccinated vs nonvaccinated patients [32]. A study conducted in the Netherlands during the 1999-2000 influenza A epidemic in a population of adults with diabetes found that vaccination was associated with a $56 \%$ reduction in any complication, a $54 \%$ reduction in hospitalizations, and a 58\% reduction in deaths [33]. It should also be kept in mind that in patients with diabetes influenza alone causes many difficulties in the proper control of blood glucose level.

Considering the above, vaccination is the best way to prevent influenza. The efficacy of the influenza vaccine is estimated at $70-90 \%$, depending on the similarity between the circulating virus and the virus contained in the vaccine, immunocompetence, and age of the patient. Although the recommendations for influenza vaccination in diabetes patients have only class $C$ according to the American Diabetes Association (ADA), the Polish Immunization Programme (PSO) for 2019, the guidelines of Diabetes Poland (PTD) from 2019, guidelines of ADA of 2019, and the College of Family Physicians for 2019 consistently advocate vaccination [34-37].
For the above reasons, experts of the Polish National Programme for Influenza Control dedicated the year 2019 to patients with diabetes. A new module: influenza and diabetes, has been made available on the e-learning website Wirtualna Akademia Grypy (Virtual Influenza Academy) to educate users about influenza and its complications (www.wirtualnaakademiagrypy.pl or www.opzg.pl)

\section{Patients with cancer}

Influenza infection is the cause of increased morbidity and mortality in patients immunocompromised because of cancer or its treatment. Influenza infection may delay or interrupt chemotherapy in cancer patients and cause their hospitalization.

Immunization by vaccination relies on the stimulation of the immune response to produce specific antibodies after controlled exposure to the antigen. However, many patients with cancer are immunodeficient as a result of disease and/or immunosuppressive therapies. For this reason a reduced serological response to influenza vaccination can be observed in this population, and these patients are at very high risk of severe illness and influenza-related complications. Misconceptions that have emerged both among patients and doctors about the lack of benefit from vaccination, as well as concerns about safety and side effects, can make vaccination difficult.

According to a Cochrane review, existing evidence for the efficacy of influenza vaccination in immunosuppressed adults with cancer mainly comes from observational studies and is incomplete, but previous studies revealed a higher incidence of influenza-related complications, including hospitalizations and deaths, in these adults compared to the general population. The available data are limited and have a low grade, but it seems that vaccination is safe and may offer benefits by alleviating the clinical symptoms of influenza as well as reducing hospitalization and mortality rates. Data on all-cause mortality from two cohort studies showed significantly lower mortality in vaccinated subjects. Evidence from studies therefore suggests the vaccination of patients with cancer [38].

Ideally, vaccination should be given to the patient before starting cancer treatment, which is rarely possible in practice, but there are no contraindications to vaccination during cancer treatment. Inactivated vaccines can be administered at any time during cancer treatment, regardless of the cancer type, as soon as vaccines for the new influenza season are available.

Cancer patients undergoing immunosuppressive therapy, in whom inactivated vaccines are not recommended and live vaccines are contraindicated, are recommended to receive annual influenza vaccination as an exception, even if they undergo intensive treatment; ideally vaccination should be given between courses of chemotherapy, and as early as possible at the beginning of the influenza season [39-41].

According to recommendations from PTiHT [42], influenza vaccination has the highest class of recommendation in cancer patients. One dose of the inactivated vaccine is administered in standard cases. Administration of a booster one month after the first dose may be considered in patients with secondary immunodeficiency.

Because some patients with immunodeficiencies of different aetiology may not respond to vaccination or not develop sufficient immunity, we recommend, in addition to vaccination, the use of the cocooning strategy in relation to these patients. This strategy involves the vaccination of people in close contact with vulnerable cancer patients, including household members and healthcare workers.

\section{Pregnant women}

Pregnant women are at increased risk of severe and complicated influenza, and for this reason WHO gives them a special and high priority by recommending influenza vaccination in each trimester of pregnancy and accepting this procedure as safe [43]. 
The risk of acquiring influenza infection in pregnant women is comparable to that observed in the general population, while the more severe course of the disease is associated with changes in the immune system (suppressed cell-mediated immunity, which promotes viral infections), elevation of the diaphragm base, increased respiratory rate, increased intra-abdominal pressure, decreased lung capacity, increased load on the vascular bed - all these conditions predispose women to respiratory tract infections and pulmonary oedema [44-46].

Descriptions of influenza pandemics that took place in the $20^{\text {th }}$ and $21^{\text {st }}$ centuries have provided spectacular evidence for including pregnant women in the group at risk of influenza-related complications and death. For example, during the 1918 influenza pandemic about $50 \%$ of pregnant women with influenza had a spontaneous abortion, and during the 1957 pandemic in the United Kingdom $50 \%$ of all deaths due to influenza were in pregnant women [47]. During the 2009 influenza pandemic in the United States, $6-10 \%$ of all deaths from influenza were in pregnant women [48]. Pregnant women accounted at that time for $63 \%$ of all patients hospitalized due to influenza and $59 \%$ of patients admitted to intensive care units [49]. Dodds et al. estimated that the risk of hospital admission due to influenza and its complications was 8 -fold higher in pregnant women with comorbidities, and the risk of complications was significantly higher in the second and third trimesters [50]. Other studies have found that pregnancy is one of the most important risk factors for admission to the ICU, and has even greater predictive value than other co-existing risk factors, such as obesity, heart failure or diabetes [51-54].

Symptoms of influenza in pregnant women are the same as in other patients, and include fever, cough, sore throat, rhinorrhea, headache, myalgia, vomiting, diarrhoea, with more frequent dyspnoea, and more severe rhinorrhea, which results from hyperthermia caused by hormonal changes $[55,56]$.

The most common influenza-related complications in pregnant women include pneumonia (in $80 \%$ of cases due to bacterial coinfection, mainly caused by Streptococcus pneumoniae, in $20 \%$ of cases due to primary infection with influenza virus), and acute respiratory failure $[44,55,56]$.

Influenza in a pregnant woman has a negative effect on both mother and infant. Studies have revealed that influenza during pregnancy is associated with a 3 - to 5 -fold higher risk of preterm delivery, miscarriage, birth of a child with low body weight, stillbirth, and infant death during the early neonatal period [57, 58], and 2-fold higher risk of delivery by caesarean section [59-61].

The influenza virus does not have teratogenic effects, but fever developing in the mother has a negative impact on the foetus by causing foetal tachyarrhythmias, and increases the risk of neonatal complications such as convulsions, encephalopathy, cerebral paralysis, neural tube defects and death [62-64].

For these reasons, influenza should be prevented in pregnant women by using an inactivated vaccine, and pregnant women who contract influenza should be diagnosed and treated promptly and correctly.

\section{Elderly patients}

The age-related deterioration of immune system function means that the risk of complications, including death, is significantly higher in elderly people than in the general population. In 2003 Thompson et al. reported that the mortality rate for influenza and pneumonia in 1990-1999 was highest in persons aged 65 years and older, and was 22.1 per 100000 person years, regardless of the influenza virus strain [65]. The rate of influenza-associated hospitalizations is even higher in this age group. For example, it was estimated at 37.9 per 100000 person years in people aged 50-64, but increases significantly in each 5-year period of life to reach 628.6 per 100000 person years in people aged 85 and older. The number of days that older people spend in the hospital due to influenza-related complications also in- creases with age [66]. Importantly, higher rates of hospitalization and mortality in this group of patients do not result from the higher incidence of influenza and influenza-like illness (ILI), but from more severe clinical symptoms and complications. Barker et al. also found that elderly patients who developed influenza experienced a significant decline in their functional status, such as independence in mobility, dressing, and bathing when assessed 3-4 months after surviving infection [67].

Immunosenescence is a term coined by the American gerontologist Dr. Roy Walford in 1969, and refers to the gradual deterioration of the immune system brought on by natural age advancement [68-70]. It involves both the host's capacity to respond to infections and the development of long-term immune memory, especially by vaccination. It has serious implications for a non-specific and specific immune response.

Despite this, elderly people probably benefit from annual influenza vaccinations more than other groups. For example, a meta-analysis by $\mathrm{Vu}$ et al. showed that in elderly patients, influenza vaccination was associated with a $33 \%$ lower rate of hospitalizations for pneumonia and influenza, and a $47 \%$ lower mortality rate due to hospitalization for pneumonia and influenza $[20,71]$. Similar conclusions were reached by Gross et al. in their meta-analysis assessing the efficacy of the influenza vaccine in elderly persons. The meta-analysis revealed a $32-45 \%$ lower rate of hospitalizations, a 31-65\% lower rate of mortality for patients hospitalized due to pneumonia, a $43-50 \%$ lower rate of mortality for patients hospitalized for all respiratory tract infections, and a $27-30 \%$ lower rate of all-cause mortality in vaccinated elderly patients $[72,73]$.

A large meta-analysis of 14 cohort studies [74] published in 2014 indicated the same conclusions even after addressing potential biases resulting from statistical errors. The influenza vaccine was still estimated as effective in preventing influenza in people aged 60 and older, reduced the risk of hospitalization for influenza-related complications, reduced the rate of mortality due to influenza-related complications, and also reduced all-cause mortality in this group of patients [74]. When the confounders in various studies were considered, the influenza vaccine was still associated with a significant reduction in the risk of mortality [75-77].

\section{Diagnosis of influenza}

\section{Clinical diagnosis, differential diagnosis}

During the epidemic season (in Poland between October and April), influenza should be diagnosed based on a clinical examination (medical interview and physical examination). Symptoms of uncomplicated influenza are listed in Table 2. It should be pointed out that influenza is a systemic disease (in contrast to the common cold), which means that during the infection patients develop typical symptoms, but clinical symptoms with sudden onset are also common:

- general symptoms: chills, confusion, weakness, lack of appetite,

- osteoarticular pain,

- drowsiness - a rare symptom in adults, but developed by about $50 \%$ of children younger than 4 years.

Laboratory tests may be helpful in diagnosing influenza infection. Leucopoenia with lymphocytosis in peripheral blood may be characteristic of influenza infection.

Differential diagnosis should consider diseases producing similar symptoms (i.e. influenza-like infections), which include infections caused by [5]:

- viruses: parainfluenza virus, RSV, enteroviruses (e.g. Coxsackie), rotaviruses, noroviruses, viral pharyngitis, infectious mononucleosis,

- bacteria: atypical pneumonia,

- fungi: Histoplasma capsulatum (histoplasmosis, Darling's disease). 


\begin{tabular}{|l|l|l|l|l|}
\hline \multicolumn{6}{|l}{ Table 2. Signs and symptoms of uncomplicated influenza helpful in diagnosis (according to [4]) } \\
\hline General & Upper respiratory & Neuromuscular & Gastrointestinal & Respiratory \\
\hline Fever & nasal congestion & myalgia & abdominal pain & pleuritic chest pain \\
\hline Chills & sore throat & arthralgia & vomiting & \\
\hline Malaise & Rhinorrhea & chest pain & diarrhoea & non-productive cough \\
\hline Fatigue & & weakness & & \\
\hline Headache & & & & \\
\hline
\end{tabular}

\begin{tabular}{|l|l|l|}
\hline Table 3. Differential diagnosis: influenza versus common cold (according to [37]) \\
\hline Characteristic features & Influenza & Cold \\
\hline Disease onset & sudden, with acute symptoms & slow, with mild symptoms \\
\hline Body temperature & high $\left(>38^{\circ} \mathrm{C}\right)$ & usually slightly elevated \\
\hline Osteoarticular pain & very common, severe & rare, mild \\
\hline Headache & very common & rare \\
\hline General wellbeing & very bad & moderately bad \\
\hline Rhinorrhea & common & very common \\
\hline Dry cough & common & rare \\
\hline Hoarseness & rare & common \\
\hline Sore throat & rare & common \\
\hline Lack of appetite & common & rare \\
\hline
\end{tabular}

The biggest problem is differentiation between influenza and the common cold (viral upper respiratory tract infection). In everyday outpatient practice, a detailed interview with the patient and physical examination can be helpful. There are many features that differentiate these two diseases (Tab. 3).

\section{Laboratory tests to confirm influenza}

Biological specimens collected from patients with suspected influenza include: nasal swab, oropharyngeal swab, nasopharyngeal swab, nasopharyngeal wash/aspirate, bronchoalveolar lavage, tracheal aspirate, cerebrospinal fluid, effusion from the middle ear, airway biopsy specimens, blood, and pericardial fluid [1].

The following techniques are used for the diagnosis of influenza $[1,78]$ :

- detection of influenza virus antigens (e.g. molecular biology techniques, immunofluorescence (currently not used in clinical diagnostics) - rapid immunochromatographic diagnostic tests;

- detection of antibodies against influenza virus (antibodies against haemagglutinin or neuraminidase): these tests are used to diagnose single cases of influenza (mainly in retrospective studies), cross-sectional serological tests (to determine what percentage of the population had contact with the virus) and to assess the efficacy of influenza vaccination.

The isolation and culture of viruses remains the gold standard for diagnosing influenza, but it should be noted that this is a labour-intensive and time-consuming method (test yield results in 3 to 14 days), not widely available, and therefore mainly used for research purposes $[1,78]$.

\section{Molecular biology techniques}

Reference methods of a clinical value are those relying on molecular biology techniques, or real time polymerase chain reaction (RT-PCR), which has the highest sensitivity and specificity, and results obtained from using other diagnostic tests are compared to it. RT-PCR tests are performed, for example, at provincial sanitary and epidemiological stations, selected hospitals (usually those with departments of infectious diseases or large multi-specialist hospitals), the National Institute of Public Health - National Institute of Hygiene (National Influenza Centre) and selected diagnostic laboratories. RT-PCR can be used to detect genetic material of the influenza virus, to identify infections caused by influenza $A$ virus (and its subtypes), e.g. $A(H 3 N 2), A(H 1 N 1)$ or type $B$ (including Victoria and Yamagata lineages). For medical practitioners, the most important thing is to confirm influenza infection (irrespective of the type, subtype or lineage of virus responsible for it), because the causal treatment of the influenza remains the same. Detailed identification of the virus type, subtype and lineage is important for virological surveillance.

Surveillance data are used to gather information about the current epidemiology of influenza in a given country and demographic region; these data are pooled and analyzed, and then used by WHO to prepare recommendations on the composition of the influenza vaccine for the upcoming season. RT-PCR tests yield results in 3-4 hours after specimens are delivered to the laboratory for analysis (the laboratory's working time should be taken into account as not all of them operate in the $24 / 7$ system). RT-PCR tests can only be done in a specialized laboratory by experienced staff $[1,78,79]$.

\section{Rapid influenza diagnostic tests - molecular assays}

Currently available point-of-care rapid diagnostic tests (POC-PCR) using molecular biology techniques allow for detecting genetic material of the influenza virus in a specimen collected from the patient. Test results are ready within 30 minutes of collecting the specimen and the analysis is fully automated. POC-PCR tests have $98.4 \%$ sensitivity and $96.5 \%$ specificity for detecting influenza virus A, and $97.9 \%$ sensitivity and $98.4 \%$ specificity for detecting influenza virus B. Rapid molecular diagnostic tests yield highly reliable results in a short time (this is their advantage over RIDT, whose sensitivity is considered to be moderate), and are also simple to perform, with an automatic interpretation of results (without the need for highly specialized and very expensive equipment, as well as highly qualified personnel, in contrast to traditional RT-PCR) [80-82].

Rapid influenza diagnostic tests - immunochromatographic assays

The advantages of the Rapid Influenza Diagnostic Test (RIDT) include easy collection of specimens for analysis (it can be a nasal swab and/or oropharyngeal swab), as well as the short time needed to obtain the result (up to 15 minutes after specimen collection), but its disadvantage is its moderate sensitivity (50-70\%). In patients with typical influenza symptoms, tested 
positive by means of a rapid influenza diagnostic test during the influenza season, the diagnosis of influenza should be regarded as certain, which allows for the implementation of causal treatment (with neuraminidase inhibitors) and necessary procedures ensuring isolation of the infected patient. In patients with typical influenza-like symptoms, tested negative by means of a rapid diagnostic test for influenza during the influenza season, the disease cannot be ruled out; therefore, if there are indications (e.g. risk of severe and complicated influenza), causal treatment should be implemented, and molecular tests may be considered to confirm/rule out infection, but decisions about starting antiviral treatment should not wait for laboratory confirmation of influenza.

The accuracy of rapid influenza diagnostic tests is most similar to that declared by the manufacturer and optimal when the prevalence of influenza in the population is $>10 \%$. Therefore, the actual local epidemiological situation has to be considered when interpreting results from RIDTs [83-87].

Depending on the manufacturer, RIDTs differ for sensitivity and specificity, time of performing and reading the test results, and the type of biological specimen recommended for testing. Some tests only detect the influenza A virus, while others detect both influenza $A$ and $B$ viruses (the use of tests detecting both types of infection is recommended). The results of tests performed in everyday work may be influenced by many factors, including: the type of test, type of biological specimen collected for analysis, duration of disease symptoms at the time of testing, the patient's age, the experience and skills of the personnel collecting biological specimens for analysis and performing rapid diagnostic test, the method and time of storage of the specimen before testing, as well as recent use (up to 2-3 weeks before the test) of the nasal attenuated influenza vaccine by the patient. The sensitivity of RIDT is higher in children because shedding of the influenza virus is more intense and longer in them. The time elapsed from the onset of the first disease symptoms to the performance of RIDT is also important (a false negative result is most likely when RIDT is performed less than 12 hours from the onset of symptoms or $>60$ hours from the onset of symptoms; in the first case the number of virus replicates is still too low, and in the second case it has already declined to a low level) [83-87].

It has been shown that rapid influenza diagnostic tests have a positive effect on clinical decisions by: reducing the number of antibiotics used in patients with influenza-like symptoms, rationalizing the use of anti-influenza drugs (oseltamivir), reducing the number of additional tests ordered, and reducing the duration of stay in the emergency department, and for these reasons RIDTs should be used, keeping in mind the limitations described above [88-90].
A test detecting the M1 protein of the influenza virus (Flu SensDx) is a novelty on the market. The principle of this test is based on electrochemical impedance spectroscopy. The diagnostic sensitivity of Flu SensDx was estimated at $91.67 \%$ and the specificity at $96.97 \%$ (manufacturer's data). The introduction of Flu SensDx into clinical practice will help assess the usefulness of this test in routine management of influenza patients [91].

To sum up, rapid diagnostic tests and molecular tests are important and useful in everyday clinical practice, although their availability in primary healthcare centres is limited due to their cost.

\section{Influenza treatment}

In most otherwise healthy people, influenza is a self-limiting and uncomplicated disease $[20,92,93]$. In such cases, symptomatic treatment is sufficient (Fig. 1).

\section{Symptomatic treatment}

We recommend the following strategies for the symptomatic treatment of influenza [37, 94]:

- $\quad$ proper hydration of the patient - the patient should drink plenty of liquids, which is crucial for controlling fever but also moisturizes airways, and facilitates breathing and the evacuation of secretions (especially important in elderly people);

- administration of antipyretics and analgesics (ibuprofen, paracetamol) to reduce the incidence of chills, myalgia and tachycardia associated with influenza. It should be emphasized, however, that there is no clinical evidence showing that antipyretic and anti-inflammatory treatment reduces the duration of influenza symptoms;

- $\quad$ patients are advised to rest and stay at home for up to 24 hours after the fever has resolved; this is of particular importance in minimizing influenza-related complications and shedding of the influenza virus;

- cough suppressants may be used if the patient has severe, exhausting, dry cough;

- use of medications reducing the swelling of the nasal mucosa - decongestants, normal saline solutions.

There is no evidence from any clinical studies in animals or humans indicating beneficial effects of natural or herbal therapy in the treatment of influenza. No recommendations exist for the use of herbal products, natural therapies or other over-the-counter (OTC) products in the symptomatic treatment of influenza in adults and children [95].

Uncomplicated influenza-like illness

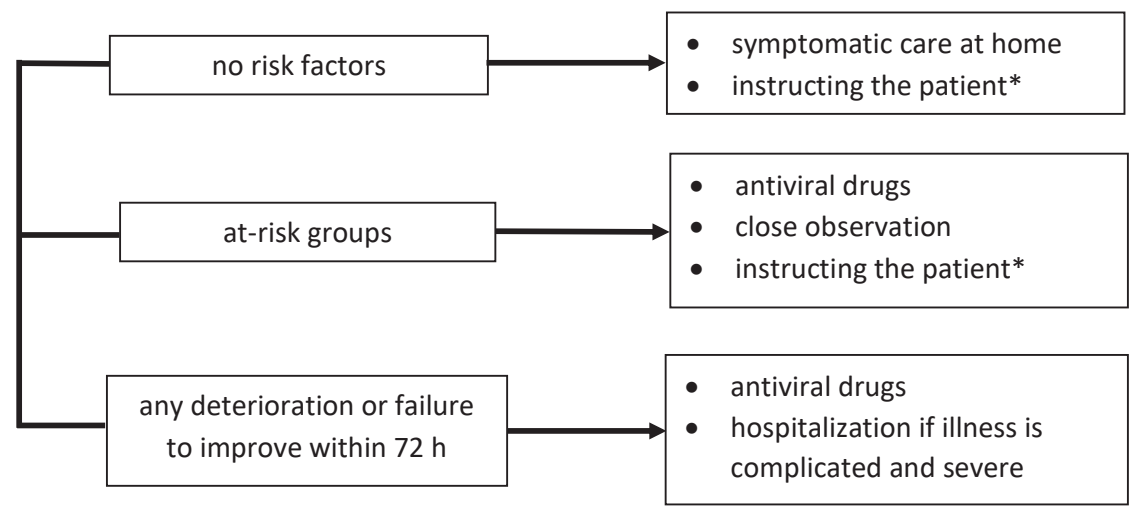

Figure 1. Initial clinical management of patients with uncomplicated influenza-like illness or influenza (according to [93])

* when the patient should return to the doctor (emergency warning signs). 


\section{Causative treatment - antiviral drugs}

Causative/antiviral treatment of influenza relies on the use of neuraminidase inhibitors:

- oseltamivir - oral dosage form,

- zanamivir - inhalation powder, a drug registered in Poland, but not available on the market.

Currently, because of the high levels of resistance observed in $\mathrm{AH} 3 \mathrm{~N} 2$ and $\mathrm{AH} 1 \mathrm{~N} 1$ viruses to amantadine and rimantadine (M2 protein inhibitors - inhibiting the release of genetic material of the influenza A virus from nucleocapsid into the host cell and further stages of viral replication), these products are not recommended in the treatment of influenza [37, 96].

Inhibitors of neuraminidase, an enzyme necessary for the replicated virions to leave the host cell, effectively inhibit the spread of the virus in the host body and prevent influenza symptoms [97]. These drugs are effective against influenza viruses $A$ and $B$. It has been estimated that less than $1 \%$ of currently existing influenza A strains are resistant to drugs. $100 \%$ of influenza B virus remains susceptible to drugs $[98,99]$. Neuraminidase inhibitors reduce the severity of influenza symptoms, reduce the duration of fever and other symptoms (on average by $21 \%$, about 25.2 hours reduction), and reduce the risk of complications (including the need for antibiotics, about $50 \%$ reduction; $\mathrm{RR}=0.56$ ) and hospitalization (over $60 \%$ reduction; $R R=0.37$ ) $[92,100,101]$. Antiviral drugs reduce the duration of necessary hospital care and hospital stay in patients with influenza, and reduce the risk of death from influenza [102].

Treatment with neuraminidase inhibitors should start as soon as possible in all patients with confirmed or suspected influenza infection, both vaccinated and unvaccinated, who meet the following criteria:

- $\quad$ patients of all ages hospitalized for influenza, regardless of the duration of illness before admission to hospital,

- $\quad$ patients with severe and rapidly progressing symptoms of influenza,

- $\quad$ patients at risk of developing influenza-related complications (tab. 4), with chronic diseases (respiratory, cardiovascular, metabolic and neurological disorders), immunocompromised patients.

Moreover, the physician should consider administering an antiviral drug to all patients with influenza symptoms lasting for 2 days or shorter time (less than 48 hours), which will significantly reduce the spread of the virus in the population, especially during the epidemic season. We especially recommend the treatment of adults who have direct, close contact with patients suffering from chronic conditions, those who are immunodeficient, and unvaccinated children (especially neonates $<6$ months of age).

Table 4. Patients at high risk of influenza-related complications (according to $[103,104]$ modified by the authors)

Recommended antiviral treatment when influenza infection is suspected or confirmed

Children aged $<5$ years, especially those aged $<2$ years

Patients aged $\geq 50$ years

Patients with chronic conditions:

- $\quad$ respiratory (including asthma),

- cardiovascular (except those with isolated hypertension),

- $\quad$ kidney disorders, liver disorders,

- blood disorders (including sickle cell haemoglobinopathies),

- metabolic disorders (including diabetes),

- neurological disorders (including disorders of CNS, spinal cord, peripheral nerves, muscles, epilepsy, stroke, mental retardation, moderate-to-severe developmental delay, brain or spinal cord injury)

Immunocompromised patients (due to therapy or infection with HIV)

All pregnant women, those planning to become pregnant, or those who gave birth during the influenza season

Patients with morbid obesity (BMI > 40)

People younger than 19 years of age on long-term aspirin- or salicylate-containing medications

People living in nursing homes

Hospitalized patients at high risk of influenza-related complications

Currently, there are 3 products containing oseltamivir registered in Poland (Tab. 5). In standard therapy the drug is administered twice a day (75 mg dose), every 12 hours, for five days (Tab. 6). Dosage increase is not recommended. It is important to complete the full 5-day treatment. The treatment should not be discontinued, even if the influenza symptoms have subsided. Longer treatment with oseltamivir ( $>5$ days) may be considered in immunocompromised patients, those hospitalized for influenza, and patients with severe influenza (e.g. severe pneumonia, ARDS). Bacteriological diagnostic tests should be considered in cases when complications or bacterial co-infection are suspected (no improvement after 3-5 days of treatment).

\begin{tabular}{|l|l|l|l|}
\hline \multicolumn{3}{|l|}{ Table 5. Drug products containing oseltamivir available on the market (according to [105-107]) } \\
\hline $\begin{array}{l}\text { Name of the } \\
\text { medicinal } \\
\text { product }\end{array}$ & Pharmaceutical form & $\begin{array}{l}\text { Therapeutic indications } \\
\text { (treatment, prevention) }\end{array}$ & $\begin{array}{l}\text { Marketing } \\
\text { authorisation } \\
\text { holder }\end{array}$ \\
\hline Tamiflu* & $\begin{array}{l}\text { hard capsules } \\
30 \mathrm{mg}, 45 \mathrm{mg}, 75 \mathrm{mg} \\
(10 \mathrm{capsules} \text { per package })\end{array}$ & $\begin{array}{l}\text { treatment of adults and children, including full term neonates; } \\
\text { post-exposure prevention of influenza in infants less than } 1 \text { year of } \\
\text { age during a pandemic influenza outbreak }\end{array}$ & Roche \\
\hline Ebilfumin* & $\begin{array}{l}\text { hard capsules } \\
30 \mathrm{mg}, 45 \mathrm{mg}, 75 \mathrm{mg} \\
(10 \mathrm{capsules} \text { per package })\end{array}$ & $\begin{array}{l}\text { treatment of adults and children, including full term neonates; } \\
\text { post-exposure prevention in individuals } 1 \text { year of age or older; } \\
\text { post-exposure prevention of influenza in infants less than } 1 \text { year of } \\
\text { age during a pandemic influenza outbreak }\end{array}$ & $\begin{array}{l}\text { TEVA Pharma- } \\
\text { ceuticals }\end{array}$ \\
\hline Tamivil & $\begin{array}{l}\text { tablets } \\
75 \mathrm{mg}(10 \text { tablets per package) }\end{array}$ & $\begin{array}{l}\text { adults and children } 6 \text { years of age or older, with body weight not } \\
\text { lower than } 40 \mathrm{~kg}\end{array}$ & Biofarm \\
\hline
\end{tabular}

Table 6. Recommended oral doses of oseltamivir in the treatment and chemoprophylaxis of influenza infection (according to [105-107])

\begin{tabular}{|l|l|l|}
\hline & Treatment (5 days) & Chemoprophylaxis (10 days) \\
\hline Adults & $75 \mathrm{mg}$ twice daily & $75 \mathrm{mg}$ once daily \\
\hline Pregnant women (all trimesters) & $75 \mathrm{mg}$ twice daily & $75 \mathrm{mg}$ once daily \\
\hline
\end{tabular}




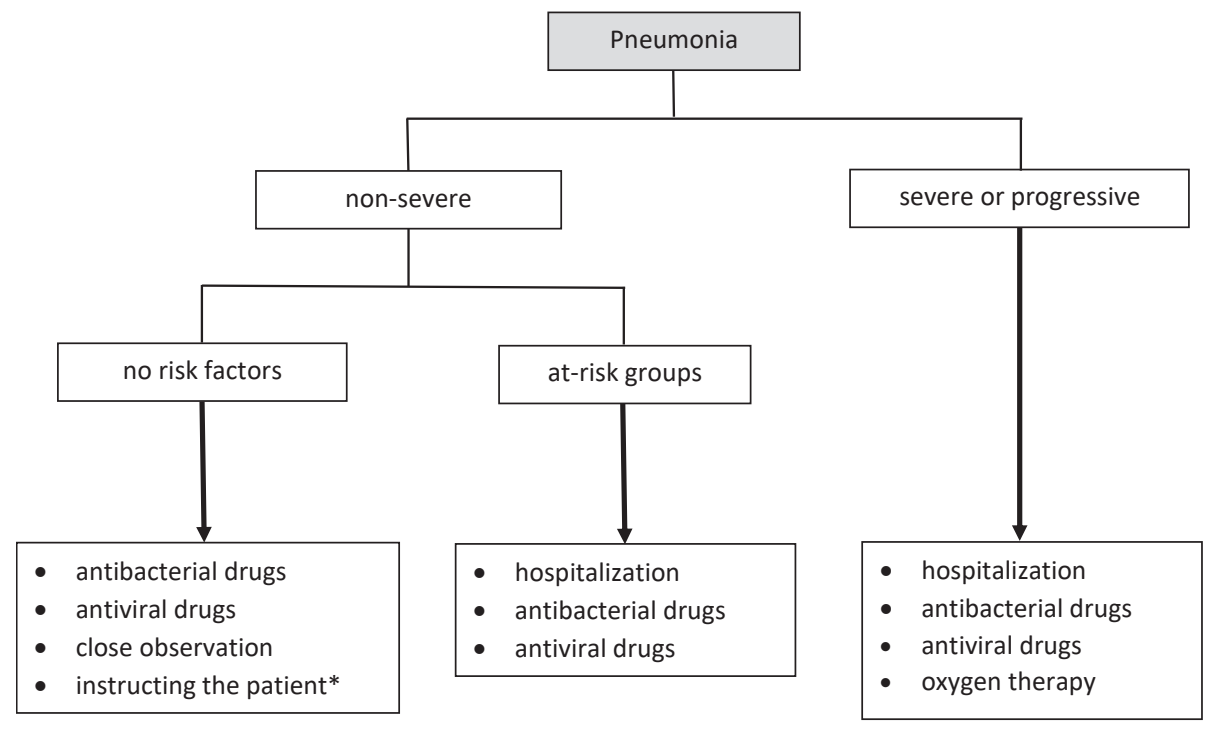

Figure 2. Initial clinical management of patients with influenza-related pneumonia (according to [21])

* when the patient should return to the doctor (emergency warning signs).

Oseltamivir treatment should start ideally within 48 hours of the onset of symptoms, and preferably as soon as possible, with no need to wait for laboratory confirmation of influenza virus infection. In exceptional cases (patients with severe confirmed influenza, those who delayed seeking medical care, patients at risk of complications), antiviral treatment can start after 48 hours of the disease onset, although the therapeutic effect may be less satisfactory [103]. Oseltamivir is an orally administered medication, and can be taken with meals or on an empty stomach. Taking oseltamivir with food may lessen the possibility of stomach upset.

Oseltamivir is a drug with a small number of undesirable effects. Most of the reported undesirable effects included single episodes of discomfort occurring on the first or second day of treatment, and resolved spontaneously within 1-2 days. Gastrointestinal symptoms such as nausea and vomiting were the most commonly reported adverse reactions (Tab. 7). The pharmacokinetic properties of oseltamivir, such as low protein binding and metabolism independent of the CYP450 and glucuronidase systems, suggest that clinically significant drug interactions via these mechanisms are unlikely.

\begin{tabular}{|c|c|c|}
\hline & Adverse reactions & Contraindications \\
\hline Tamiflu & $\begin{array}{ll}\text { - } & \text { nausea, vomiting, diar- } \\
\text { - } & \text { rhoea } \\
\text { - } & \text { headominal pain } \\
\text { - } & \text { insomnia dizziness } \\
\end{array}$ & $\begin{array}{l}\text { hypersensitivity to } \\
\text { oseltamivir phosphate } \\
\text { or to any of the excipi- } \\
\text { ents used in the drug }\end{array}$ \\
\hline Ebiflumin & $\begin{array}{ll}\text { - } & \text { nausea and vomiting } \\
\text { - } & \text { headache, dizziness } \\
\text { - } & \text { rare: cardiac arrhyth- } \\
& \text { mia, altered level of } \\
& \text { consciousness, convul- } \\
& \text { sions }\end{array}$ & $\begin{array}{l}\text { hypersensitivity to the } \\
\text { active substance or to } \\
\text { any of the excipients } \\
\text { used in the drug }\end{array}$ \\
\hline Tamivil & $\begin{array}{ll}\text { - } & \text { headache, dizziness } \\
\text { - } & \text { abdominal pain } \\
\text { - } & \text { nausea and vomiting } \\
\text { - } & \text { rare: cardiac arrhythmia, } \\
& \text { altered level of con- } \\
& \text { sciousness, convulsions }\end{array}$ & $\begin{array}{l}\text { hypersensitivity to the } \\
\text { active substance or to } \\
\text { any of the excipients } \\
\text { used in the drug }\end{array}$ \\
\hline
\end{tabular}

Importantly, treatment with oseltamivir is not a substitute for annual influenza vaccination. Patients are protected against influenza only as long as they are taking oseltamivir. The drug should be used to treat and prevent influenza only if reliable epidemiological data indicate that the virus is circulating in the environment and the symptoms suggest influenza infection.

It is advisable to consider the hospitalization of patients with severe or progressive influenza. Symptoms of pneumonia in patients at risk of developing influenza-related complications indicate the need for hospitalization (Fig. 2). Indications for the hospitalization of influenza patients are presented in Table 8. Patients with respiratory failure should be transferred to a medical centre where extracorporeal transmembrane oxygenation is available (ECMO).

Table 8. When hospitalization of the patient with influenza should be considered (according to [94], modified by the authors) Indications for hospitalization
1) significant dehydration
2) severe or rapidly progressing illness
3) pneumonia in patients at risk of developing complications
4) respiratory failure and hypoxia
5) cardiovascular and respiratory disorders
6) disorders of consciousness

\section{Antiviral drugs in the prevention of influenza}

Influenza vaccination should be recommended to all patients who have no contraindications to it, including throughout the influenza season. Nevertheless, preventive use of oseltamivir may be recommended to limit the spread of the virus and the onset of the disease in individuals who had contact with patients suffering from influenza. Post-exposure prevention is recommended in nonvaccinated individuals (who had contact with patients having clinically diagnosed influenza) and [92, 93]:

- $\quad$ are at high risk of developing complications (Tab. 4),

- are close contacts of the ill persons (they live in the same household),

- $\quad$ take care of infants younger than 6 months of age.

Pre-exposure prevention can be used in exceptional situations. It is recommended in people at high risk of developing influenza-related complications (e.g. patients with significant immunodeficiency) who cannot be protected by vaccination. 


\section{Treatment of special populations of patients}

\section{Elderly patients}

There are no data from randomized, controlled clinical trials evaluating antiviral therapy for influenza in this age group. Oseltamivir in these patients is used without dose adjustment [108]. Patients with kidney disorders require special concern.

\section{Patients with liver failure}

No reduction of therapeutic or preventive doses is necessary in these patients [109].

\section{Patients with renal impairment}

In adults (especially those older than 65 years) with renal impairment, the dose should be adjusted (reduced) based on creatinine clearance $[103,109]$. Recommended dosage in the treatment and chemoprophylaxis of influenza is presented in Table 9.

\begin{tabular}{|c|c|c|}
\hline $\begin{array}{l}\text { Creatinine clear- } \\
\text { ance }\end{array}$ & $\begin{array}{l}\text { Recommended } \\
\text { dose for treatment }\end{array}$ & Chemoprophylaxis \\
\hline$>60(\mathrm{ml} / \mathrm{min})$ & $75 \mathrm{mg}$ twice daily & $75 \mathrm{mg}$ once daily \\
\hline$>30$ to $60(\mathrm{ml} / \mathrm{min})$ & $30 \mathrm{mg}$ twice daily & $30 \mathrm{mg}$ once daily \\
\hline$>10$ to $30(\mathrm{ml} / \mathrm{min})$ & $30 \mathrm{mg}$ once daily & $\begin{array}{l}30 \mathrm{mg} \text { every second } \\
\text { day }\end{array}$ \\
\hline$\leq 10(\mathrm{ml} / \mathrm{min})$ & not recommended & not recommended \\
\hline $\begin{array}{l}\text { Haemodialysis } \\
\text { patients }\end{array}$ & $\begin{array}{l}30 \mathrm{mg} \text { after every } \\
\text { haemodialysis } \\
\text { session }\end{array}$ & $\begin{array}{l}30 \text { mg after every } \\
\text { second haemodialy } \\
\text { sis session }\end{array}$ \\
\hline $\begin{array}{l}\text { Peritoneal haemo- } \\
\text { dialysis patients }\end{array}$ & $30 \mathrm{mg}$ single dose & $30 \mathrm{mg}$ once weekly \\
\hline
\end{tabular}

\section{Immunocompromised patients}

Influenza viral replication in the respiratory tract can be prolonged, and the emergence of resistant variants during or after antiviral treatment can occur more frequently in immunocompromised patients than in immunocompetent patients [108]. Therefore, we recommend extending oseltamivir treatment to 10 days in standard doses in immunocompromised patients, especially those with severe influenza. Data from clinical studies indicate the safety and efficacy of this management strategy $[110,111]$. Increase of the daily dose in these patients is not recommended.

\section{Treatment for influenza in pregnant women}

Pregnant women are at higher risk of developing complications and severe influenza compared to non-pregnant women due to pregnancy-related physiological changes in the immune, respiratory and cardiovascular systems. Another group at risk of complications and severe influenza are women up to 2 weeks after the end of pregnancy (either after delivery or miscarriage) $[48,112]$.

Neuraminidase inhibitors: oseltamivir, zanamivir, peramivir and baloksavir are antiviral drugs licensed for the treatment of influenza in women in all trimesters of pregnancy and in the postpartum period [113].

In Poland, as mentioned earlier, only oseltamivir is registered and available on the market. Recommendations for the use of this drug in the treatment and prevention of influenza in pregnant women are presented below. In addition, oral oseltamivir is preferred for the treatment of influenza in pregnant women, since most of the available safety data concern this dosage form. Currently, almost all influenza viruses circulating in the population are sensitive to oseltamivir [113-117].

Causative treatment with oseltamivir in pregnant women reduces the risk of hospitalization at the intensive care unit, re- duces the risk of mortality from influenza and influenza-related complications, and also reduces the duration of hospitalization $[48,118,119]$

Treatment with oseltamivir in pregnant women within 48 hours of the onset of influenza symptoms is ideal, but studies demonstrated the benefit of antiviral treatment even when treatment was started more than 48 hours after illness onset [119]. The recommended oral dose for the treatment of influenza in pregnant women is $75 \mathrm{mg}$ twice daily for 5 days. Patients hospitalized at the intensive care unit for severe and complicated influenza may require longer treatment.

Decisions about starting antiviral treatment should not wait for laboratory confirmation of influenza, since delay may reduce the efficacy of therapy. A negative result of the rapid influenza diagnostic test (RIDT) in women presenting with typical influenza-like symptoms, in the season of increased incidence of influenza, does not rule out influenza, so the decision about starting antiviral treatment can be made empirically.

No controlled clinical trials assessing the safety of oseltamivir in pregnant women have been conducted, but numerous observational studies of oseltamivir treatment during pregnancy have confirmed its safety $[114,116,117,120-122]$.

\section{Chemoprophylaxis of influenza in pregnant women}

Oseltamivir is registered for the chemoprophylaxis of influenza in pregnant women. The recommended dose of oseltamivir for the prevention of influenza in pregnant women is $75 \mathrm{mg}$ once daily. Post-exposure antiviral prevention should be continued for 7 days following the last known exposure. Antiviral chemoprophylaxis with oseltamivir may be considered in pregnant women and those up to 2 weeks after the end of pregnancy (either after delivery or miscarriage) who are close contacts of people suffering from influenza and $[113,123]$ :

- cannot receive influenza vaccine due to existing medical contraindications or if the vaccine is unavailable,

- have significant immunodeficiency.

Close contacts of persons with influenza are defined as:

- people caring for someone with influenza or living in the same household with a person who has confirmed or suspected influenza,

- $\quad$ people staying in areas where there is a high probability of influenza transmission.

Pregnant women and women up to 2 weeks after delivery (or miscarriage), who received oseltamivir for the chemoprophylaxis of influenza should be informed that $[113,123]$ :

- chemoprophylaxis reduces but does not completely eliminate the risk of contracting influenza,

- the protective effect stops when the drug is discontinued.

Early antiviral treatment with oseltamivir, started after the onset of the first symptoms of influenza in pregnant women or women in the postpartum period, is an alternative to chemoprophylaxis, so clinical evaluation is an important factor in making decisions regarding causative treatment of influenza $[113,123]$.

\section{Influenza prevention - vaccination}

The most effective way to prevent influenza and its complications is vaccination [124]. Annual vaccinations are needed due to the high variability of influenza viruses and their frequent mutations; as a consequence, WHO updates its recommendations on the vaccine's composition each year; in addition, the immune response to influenza vaccines is short-lasting and is unlikely to persist for longer than one year [125]

Epidemiological and virological data on influenza are gathered by the Global Influenza Surveillance Network (GISN), and are used to anticipate the virus strains that will most likely dominate during the upcoming influenza season and make decisions on the vaccine's composition [126]. Each year in February WHO publishes recommendations on the composition of a trivalent 
vaccine (containing two strains of influenza $A$ virus and one strain of influenza B) and a quadrivalent vaccine containing an additional second influenza $B$ strain, separately for the northern and southern hemispheres (WHO 2019). WHO recommends the use of a quadrivalent influenza vaccine, which provides broader protection against influenza virus $B$.

Recommendations for the annual use of the influenza vaccine in Poland are presented in the Polish Immunization Programme (PSO), published in October for the upcoming year [127]. These recommendations are prepared based on the analysis of the health-related costs of influenza, the efficacy, immunogenicity and safety of vaccines, and the objectives of health policy.

We recommend offering seasonal influenza vaccine to patients as soon as it is available in autumn, since the beginning of the influenza season is difficult to predict, and the seasonal influenza outbreak may begin in the Northern Hemisphere as early as in November. Although we strongly advise vaccination before the start of the influenza season, the vaccine can be given throughout the season. Although post-exposure influenza immunization may have lower efficacy, every opportunity should be used to vaccinate individuals from at risk groups who have not yet been immunized during the current season, even after the start of the influenza season.

\section{Influenza vaccines available in Poland}

Influenza vaccines currently available on the Polish market are inactivated subunit vaccines or split vaccines (with the split virion). According to available data, there are no differences in their immunogenicity. There are four inactivated influenza vaccines registered in Poland: Vaxigrip, Vaxigrip Tetra, Influvac, and Influvac Tetra. In the current season only quadrivalent vaccines are available (Tetra). A live attenuated influenza vaccine (LAIV: Fluenz Tetra) is available for the $2019 / 2020$ season, and it was registered for use in children aged between 2 and 18 years.

These vaccines mainly induce humoral immunity against viral surface proteins, primarily haemagglutinin ( $\mathrm{HA})$, and to a lesser extent against neuraminidase, specific for a given influenza virus subtype. Specific anti-HA antibodies are considered protective, and therefore vaccines contain their standardized amount, typically $15 \mu \mathrm{g}$ HA from each strain. The haemagglutination inhibition assay is considered as a correlate of protection for influenza vaccines. An HA antibody titer of 40 or more is generally regarded as a protective threshold level, beyond which there is a less than $50 \%$ chance of contracting influenza infection. The protective effect against infection increases to a titre of 160 , and above this level the additional protective effect is minimal $[128,129]$.

The influenza vaccine is safe and well tolerated. The influenza vaccine cannot cause influenza illness because inactivated influenza vaccines do not contain live virus, and live attenuated influenza vaccines contain weakened viruses that can only replicate in the nasal mucosa [130].

The inactivated influenza vaccine (IIV) is less immunogenic in young children and does not provide sufficient protection, which is why the currently available vaccines are not licensed for use in infants younger than 6 months [131].

\section{Recommendation for influenza vaccination}

The goal of annual influenza immunization is to prevent serious illness caused by influenza and its complications, including hospitalization and death [130].

We recommend that the influenza vaccine should be offered each year to all individuals aged 6 months and older who have no contraindications for vaccination, especially to the groups for whom influenza vaccination is particularly recommended. We recommend that the influenza vaccine should be offered as a priority to the groups for whom the influenza vaccination is particularly recommended (Tab. 10).
Table 10. Groups for whom the influenza vaccine is particularly recommended (based on the Canadian Immunization Guide)

People at high risk of influenza-related complications or hospitalization

All pregnant women

Adults and children with the following chronic health conditions:

- cardiac or pulmonary disorders (includes bronchopulmonary dysplasia, cystic fibrosis, COPD and asthma);

- diabetes mellitus and other metabolic diseases;

- cancer, immune-compromising conditions (due to underlying disease, therapy, or both);

- renal disease;

- anaemia or haemoglobinopathy;

- neurologic or neurodevelopment conditions (includes neuromuscular, neurovascular, neurodegenerative, neurodevelopmental conditions, and seizure disorders [and, for children, includes febrile seizures and isolated developmental delay], but excludes migraines and psychiatric conditions without neurological conditions;

- morbid obesity (body mass index [BMI] $>40$ );

- children 6 months to 18 years of age undergoing treatment for long periods with acetylsalicylic acid, because of the potential increase of Reye's syndrome associated with influenza

People of any age who are residents of nursing homes and other chronic care facilities

Adults 65 years of age and older

All children 6-59 months of age

People capable of transmitting influenza to those at high risk

Healthcare and other care providers in facilities and community settings who, through their activities, are capable of transmitting influenza to those at high risk

Household contacts, both adults and children, of individuals at high risk, whether or not the individual at high risk has been vaccinated:

- household contacts of infants less than 6 months of age, as these infants are at high risk but cannot receive the influenza vaccine;

- members of a household expecting a newborn during the influenza season;

- people providing regular child care to children 6-59 months of age, whether in or outside the home

People who provide services within closed or relatively closed settings to people at high risk (e.g. crew on a ship, crew on a plane) Others

People who provide essential community services (fire-fighters, police, city cleaning services, public transport workers, teachers, shop workers)

People who are in direct contact with poultry

\section{Vaccination procedure}

Inactivated vaccines are injected intramuscularly into the deltoid muscle in older children and adults (for patients with haemophilia, the vaccine is injected subcutaneously). A single dose of vaccine is injected $(0.5 \mathrm{ml})$.

We recommend that, if necessary, all seasonal influenza vaccines may be considered for administration at the same time as, or at any time before or after, the administration of other live attenuated or inactivated vaccines. Different injection sites and separate needles and syringes should be used for concomitant injections.

\section{Contraindications to vaccination}

Influenza vaccination should not be given to:

- people who have had an anaphylactic reaction to a previous dose of influenza vaccine;

- $\quad$ people who have had an anaphylactic reaction to any of the vaccine's components; 


\section{Precautions}

We recommend that the influenza vaccination should be postponed in people with serious acute illnesses, including those with fever, until their symptoms have subsided. We recommend that vaccination should not be delayed because of minor infection, with or without fever.

\section{Egg allergy}

Inactivated influenza vaccines are prepared by the propagation of virus in embryonated hen's eggs and might contain trace amounts of egg proteins, such as ovoalbumin. Therefore, the risk of allergic reactions to influenza vaccines should be considered.

There is now a consensus that influenza vaccines containing less than $0.12 \mu \mathrm{g} / \mathrm{ml}$ of ovoalbumin are safe for use in people with egg allergy, and clinical studies demonstrated that influenza vaccines with a content less than $0.7 \mu \mathrm{g}$ of ovoalbumin per dose have been tolerated by patients without serious reactions. Influenza vaccines available in Poland contain from $\leq 0.05 \mu \mathrm{g}$ (Vaxigrip Tetra) to $<0.1 \mu \mathrm{g}$ (Influvac Tetra/Influvac) of ovoalbumin per vaccine dose, which means these vaccines are safe for use in people with egg allergy.

The safety of inactivated influenza vaccines in people with allergy to egg protein (including severe allergy) has been confirmed in clinical studies. No postvaccination observation period is recommended for egg-allergic persons. However, ACIP recommends that vaccine providers consider observing patients (seated) for $\mathbf{1 5}$ minutes after the administration of any vaccine to decrease the risk of injury should syncope occur [132].

\section{Guillain-Barré Syndrome (GBS)}

A history of Guillain-Barré Syndrome (GBS) within 6 weeks of a previous dose of influenza vaccine is considered a precaution to vaccination. Benefits and risks should be considered in such patients: vaccination should be considered in persons who are at risk of severe influenza complications; in other cases the influenza vaccine generally should not be given [132].

\section{Rationale supporting vaccination and the choice of at risk groups}

Children younger than 5 years, individuals older than 60 or 65 years of age, individuals with chronic medical conditions (especially chronic cardiovascular and respiratory diseases, diabetes mellitus and some other conditions for which a high risk of influenza-related complications is demonstrated), individuals with morbid obesity and pregnant women are widely regarded to have a high risk of severe influenza. Moreover, the vaccination of healthcare workers is recommended in many countries to prevent the transmission of influenza to patients $[130,133]$.

In 2012 the WHO's Strategic Advisory Group of Experts (SAGE) released a position statement targeting five at risk groups: children younger than 5 years (especially those aged under 2 years), elderly people, individuals with chronic medical conditions, pregnant women and healthcare workers. The WHO recommends that pregnant women should have the highest priority, since they are at high risk of complications and hospitalization, the vaccine is safe for pregnant women, and there are data indicating that vaccination can also provide protection against influenza to infants who are too young to receive the vaccine [134]. There are many studies on the efficacy and safety of influenza vaccination in pregnant women. The results of a Canadian study published in 2019 in the British Medical Journal confirmed the safety of influenza vaccination during pregnancy in mothers and children. No association was observed between exposure to the $A(H 1 N 1) p d m 09$ pandemic influenza vaccine during pregnancy and most five year paediatric health outcomes [135].
Although in most countries national immunization strategies focus on recommendations for people at increased risk of developing severe influenza or influenza-related complications, and individuals who are capable of transmitting influenza to those at high risk at work or in the home setting, influenza vaccination is recommended for all individuals who are aged 6 months or older and want to reduce the risk of contracting influenza and the development of influenza-related complications.

In 2010 ACIP simplified a recommendation that universal annual vaccination be administered to all persons aged $\geq 6$ months in the United States. This strategy, although not adopted by other countries, resulted from the ongoing expansion of target groups, especially in the years 2000-2009, when over $80 \%$ of people belonged to at least one target group for vaccination. It has been assumed in these universal recommendations that all individuals are at risk of influenza and severe disease. This simplified aged-based influenza vaccine recommendation is also expected to improve vaccine coverage levels in high-risk groups [136]. In conclusion, we recommend annual influenza vaccination to all individuals aged 6 months or older, provided that there are no absolute contraindications to it. Vaccination before the start of each influenza season should primarily be used by individuals at increased risk of severe influenza and complications, and - for epidemiological reasons - by individuals who are capable of transmitting the influenza virus to those at risk. People who provide essential community services, and people who are in direct contact with poultry should also be vaccinated.

\section{Summary of recommendations}

1. Annual influenza vaccination is recommended for all individuals aged 6 months or older, provided that there are no absolute contraindications to it.

2. Patients from at risk groups and people who are capable of transmitting the influenza virus to patients from at risk groups should be actively encouraged to receive influenza vaccination.

3. Healthcare workers should have an annual influenza vaccination to protect themselves, their families, and patients.

4. Patients should be offered seasonal influenza vaccination early in autumn, because the start of the influenza season is difficult to predict. Vaccination can be given throughout the influenza season.

5. The cocooning strategy (vaccination of close contacts) should be used in relation to patients who cannot receive the vaccine, or those who may not respond to vaccination and are at risk of severe and complicated influenza.

6. Influenza vaccination does not prevent infection completely.

7. During the epidemic season influenza should be diagnosed based on a clinical examination and current epidemiological data.

8. Diagnostic tests detecting the influenza virus may be useful in diagnosing influenza but are not indispensable to diagnose outpatients during the epidemic season.

9. Decisions about starting antiviral treatment should not wait for laboratory confirmation of influenza in patients at risk.

10. Neuraminidase inhibitors are the only drugs recommended for the treatment and chemoprophylaxis of influenza.

11. Treatment with neuraminidase inhibitors is recommended for all patients with confirmed or suspected influenza who: a) are at risk of developing influenza-related complications and severe influenza,

b) have severe or rapidly progressing illness, c) are hospitalized.

12. The greatest clinical benefit occurs when treatment is initiated early, within 48 hours of influenza onset. Antiviral drugs can provide benefits to patients with severe, complicated or progressive illness, and to those hospitalized when influenza treatment was started 48 hours or more after the onset of symptoms. 
Source of funding: This work was funded from the authors' own resources.

Conflicts of interest: The authors declare no conflicts of interest.

\section{References}

1. Brydak L. Pandemia grypy. Mit czy realne zagrożenie? Warszawa: Oficyna Wydawnicza Rytm; 2008: 125-141 (in Polish).

2. ECDC. Seasonal Influenza. Factsheet for health professionals 2017 [cited 24.10.2019]. Available from URL: https://www.ecdc.europa. eu/en/seasonal-influenza/facts/factsheet.

3. Krajowy Ośrodek ds. Grypy - Meldunki Epidemiologiczne PZH. Available from URL: http://wwwold.pzh.gov.pl/oldpage/epimeld/ grypa/2019/G_19_02B.pdf (in Polish).

4. Uyeki TM, Bernstein HH, Bradley JS, et al. Clinical practice guidelines by the Infectious Diseases Society of America: 2018 update on diagnosis, treatment, chemoprophylaxis, and institutional outbreak management of seasonal influenza. Clin Infect Dis 2019; 68(6): 895-902.

5. Centers for Disease Control and Prevention [cited 24.10.2019]. Available from URL: http://www.cdc.gov/ncidod/dbmd/diseaseinfo.

6. Naghavi M, Wyde P, Litovsky S, et al. Influenza infection exerts prominent inflammatory and thrombotic effects on the atherosclerotic plaques of apolipoprotein E-deficient mice. Circulation 2003; 107(5): 762-768.

7. Pleskov VM, Bannikov Al, Ză̌tsev lu V. [The receptor-mediated endocytosis of influenza viruses and low-density lipoproteins by tissue cells]. Vopr Virusol 1994; 39(3): 121-125 (in Russian).

8. Stewart S, McIntyre K, Capewell S, et al. Heart failure in a cold climate. Seasonal variation in heart failure-related morbidity and mortality. J Am Coll Cardiol 2002; 39(5): 760-766.

9. Sandoval C, Walter SD, Krueger P, et al. Risk of hospitalization during influenza season among a cohort of patients with congestive heart failure. Epidemiol Infect 2007; 135(4): 574-582.

10. Madjid M, Miller CC, Zarubaev VV, et al. Influenza epidemics and acute respiratory disease activity are associated with a surge in autopsy-confirmed coronary heart disease death: results from 8 years of autopsies in 34,892 subjects. Eur Heart J 2007; 28(10): 1205-1210.

11. Barnes $M$, Heywood AE, Mahimbo A, et al. Acute myocardial infarction and influenza: a meta-analysis of case-control studies. Heart 2015; 101(21): 1738-1747, doi: 10.1136/heartjnl-2015-307691.

12. Maclntyre CR, Mahimbo A, Moa AM, et al. Influenza vaccine as a coronary intervention for prevention of myocardial infarction. Heart 2016; 102(24): 1953-1956, doi: 10.1136/heartjnl-2016-309983.

13. 2016 European Guidelines on cardiovascular disease prevention in clinical practice. Eur Heart J 2016; 37: 2315-2381, doi: 10.1093/ eurheartj/ehw106.

14. 2019 ESC guidelines for the diagnosis and management of chronic coronary syndromes. Eur Heart J 2019; 1-71, doi: 10.1093/eurheartj/ehz425.

15. Vejpongsa $\mathrm{P}$, Kitkungvan $\mathrm{D}$, Madjid M, et al. Outcomes of Acute myocardial infarction in patients with influenza and other viral respiratory infections. Am J Med 2019; 132(10): 1173-1181, doi: 10.1016/j.amjmed.2019.05.002.

16. Christiansen CF, Thomsen RW, Schmidt M, et al. Influenza vaccination and 1-year risk of myocardial infarction, stroke, heart failure, pneumonia, and mortality among intensive care unit survivors aged 65 years or older: a nationwide population-based cohort study. Intensive Care Med 2019; 45(7): 957-967, doi: 10.1007/s00134-019-05648-4.

17. Podolec P, Kopeć G. Szczepienie przeciw grypie w prewencji chorób sercowo-naczyniowych. Forum Profilaktyki 2007; 2(7): 3-4 (in Polish).

18. Rezkalla SH, Kloner RA. Influenza-related Viral Myocarditis. WMJ 2010; 109(4): 209-213.

19. Ito T, Akamatsu K, Fujita SI, et al. Transient depression of myocardial function after influenza virus infection: a study of echocardiographic tissue imaging. PLoS ONE 2019; 14(8): e0221628, doi: 10.1371/journal.pone.0221628.

20. Antczak A, red. Grypa. Praktyczne kompendium. Warszawa: Medical Tribune Polska; 2015 (in Polish).

21. Hewitt R, Farne $H$, Ritchie $A$, et al. The role of viral infections in exacerbations of chronic obstructive pulmonary disease and asthma. Ther Adv Respir Dis 2016; 10(2): 158-174.

22. Mulpuru S, Li L, Ye L, et al. Serious Outcomes Surveillance (SOS) Network of the Canadian Immunization Research Network (CIRN). Effectiveness of influenza vaccination on hospitalizations and risk factors for severe outcomes in hospitalized patients with COPD. Chest 2019; 155(1): 69-78.

23. Poole PJ, Chacko E, Wood-Baker RW, et al. Influenza vaccine for patients with chronic obstructive pulmonary disease. Cochrane Database Syst Rev 2006; 1: CD002733.

24. Huang $\mathrm{CL}$, Nguyen $\mathrm{PA}$, Kuo $\mathrm{PL}$, et al. Influenza vaccination and reduction in risk of ischemic heart disease among chronic obstructive pulmonary elderly. Comput Methods Programs Biomed 2013; 111(2): 507-511.

25. IDF Diabetes Atlas. International Diabetes Federation, 2017. Dostępny na URL: http://www.diabetesatlas.org.

26. Casqueiro J, Casqueiro J, Alves C. Infections in patients with diabetes mellitus: a review of pathogenesis. Indian J Endocrinol Metab 2012; 16(Suppl. 1): S27-S36, doi: 10.4103/2230-8210.94253.

27. Geerlings SE, Hoepelman AI. Immune dysfunction in patients with diabetes mellitus (DM). FEMS Immunol Med Microbio/ 2000; 26(3-4): 259-265, doi: 10.1111/j.1574-695X.1999.tb01397.x.

28. Remschmidt C, Wichmann $\mathrm{O}$, Harder T. Vaccines for the prevention of seasonal influenza in patients with diabetes: systematic review and meta-analysis. BMC Medicine 2015; 13: 53, doi: 10.1186/s12916-015-0295-6.

29. Lau D, Eurich DT, Majumdar SR, et al. Working age adults with diabetes experience greater susceptibility to seasonal influenza: a population based cohort study. Diabetologia 2014; 57: 690-698.

30. Alling DW, Blackwelder WC, Stuart-Harris CH. A study of excess mortality during influenza epidemic in the United States, $1968-1976$. Am J Epidemiol 1981; 113; 30-43.

31. Allard R, Leclerc P, Trembay C, et al. Diabetes and severity of pandemic influenza A (H1N1) infection. Diabetes Care 2010; 33(7): 1491-1493, doi: 10.2337/dc09-2215.

32. Vamos EP, Pape UJ, Curcin V, et al. Effectiveness of the influenza vaccine in preventing admission to hospital and death in people with type 2 diabetes. CMAJ 2016; 188(14): E342-351, doi: /doi.org/10.1503/cmaj.151059.

33. Looijmans-Van der Akker I, Verheij TJ, Buskens E, et al. Clinical effectiveness of first and repeat influenza vaccination in adult and elderly diabetic patients. Diabetes Care 2006; 29(8): 1771-1776.

34. Zalecenia kliniczne dotyczące postępowania u chorych na cukrzycę 2019. Stanowisko Polskiego Towarzystwa Diabetologicznego. Diabetol Prakt 2019; 5(1): 1-101 (in Polish).

35. American Diabetes Association - Standards of medical care in diabetes - 2019. Diabetes Care 2019; 42(Suppl. 1): S36-S39, doi: 10.2337/dc19-Sint01. 
36. Załącznik do komunikatu Głównego Inspektora Sanitarnego z dnia 16 października 2019 r. w sprawie Programu Szczepień Ochronnych na rok 2020 [cited 20.10.2019]. Available from URL: http://dziennikmz.mz.gov.pl/api/DUM_MZ/2019/87/journal/5727 (in Polish).

37. Makowiec-Dyrda M, Tomasik T, Windak A, et al. Profilaktyka i leczenie grypy. Wytyczne Kolegium Lekarzy Rodzinnych w Polsce 2016 [cited 20.10.2019]. Available from URL: https://klrwp.pl/strona/225/wytyczne-grypa-2016/pl (in Polish).

38. Bitterman R, Eliakim-Raz N, Vinograd I, et al. Influenza vaccines in immunosuppressed adults with cancer. Cochrane Database Syst Rev 2013; 10: CD008983, doi. 10.1002/14651858.

39. Ariza-Heredia E, Chemaly R. Practical review of immunizations in adult patients with cancer. Hum Vaccin Immunother 2015; 11(11): 2606-2614.

40. Vaccine Recommendations and Guidelines of the ACIP: Altered Immunocompetence [cited 11.11.2019]. Available from URL: https:// www.cdc.gov/vaccines/hcp/acip-recs/general-recs/immunocompetence.html.

41. Robin C, Beckerich F, Cordonnier C. Immunization in cancer patients: where we stand. Pharmacol Res 2015; 92: 23-30.

42. Hus I, Piekarska A, Roliński J, et al. Szczepienia ochronne u dorosłych chorych na nowotwory hematologiczne oraz u chorych z asplenią - zalecenia PTHiT i sekcji do spraw zakażeń PALG. Acta Haematologica Polonica 2019 [cited 29.10.2019]. Available from URL: https:// doi.org/10.2478/ahp-2018-0016 (in Polish).

43. Global Advisory Committee on Vaccine Safety. Safety of immunization during pregnancy. A review of the evidence. WHO 2014 (cited 12.11.2019). Available from URL: https://www.who.int/vaccine_safety/publications/safety_pregnancy_nov2014.pdf.

44. Rasmussen SA, Jamieson DJ, Bresee JS. Pandemic influenza and pregnant women. Emerg Infect Dis 2008; 14: 95-100.

45. Schaberg T, Bauer T, Dalhoff K. Management der neuen Influenza A/H1N1-Virus-Pandemie im Krankenhaus: Eine Stellungnahme der Deutschen Gesellschaft für Pneumologie und Beatmungsmedizin. Pneumologie 2009; 63: 417-425.

46. CDC: Novel Influenza A(H1N1) Virus Infections in Three Pregnant Women - United States, April-May 2009, Centers for Disease Control and Prevention 15 May 2009. MMWR Morb Mortal Wkly Rep 2009; 58(18): 497-500.

47. Satpathy HK, Lindsay M, Kawwass JF. Novel H1N1 virus infection and pregnancy. Post-Grad Med 2009; 121: $106-112$.

48. Louie JK, Acosta M, Jamieson DJ, et al. Severe 2009 H1N1 influenza in pregnant and postpartum women in California. N Engl J Med 2010; 362: 27-35.

49. Louie JK, Acosta M, Winter K, et al. Factors associated with death or hospitalization due to pandemic 2009 influenza $A(H 1 N 1)$ infection in California. JAMA 2009; 302: 1896-1902.

50. Dodds L, McNeil SA, Fell DB, et al. Impact of influenza exposure on rates of hospital admissions and physician visits because of respiratory illness among pregnant women. CMAJ 2007; 176: 463-468.

51. Ellington SR, Hartman LK, Acosta M, et al. Pandemic 2009 influenza A(H1N1) in 71 critically ill pregnant women in California. Am J Obstet Gynecol 2011; 204: S21-S30.

52. Varner MW, Rice MM, Anderson B, et al. Influenza-like illness in hospitalized pregnant and postpartum women during the 2009-2010 H1N1 pandemic. Obstet Gynecol 2011; 118: 593-600.

53. Hanslik T, Boelle PY, Flahault A. Preliminary estimation of risk fac-tors for admission to intensive care units and for death in patients infected with A(H1N1)2009 influenza virus, France, 2009-2010. Version 1. PLoS Curr 2010; 2, doi: 10.1371/currents.RRN1150.

54. Karlsson EA, Marcelin G, Webby RJ, et al. Review on the impact of pregnancy and obesity on influenza virus infection. Influenza Other Respi Viruses 2012; 6: 449-460.

55. Laibl VR, Sheffield JS. Influenza and pneumonia in pregnancy. Clin Perinatol 2005; 32: 727-738.

56. Szenborn L, Matkowska-Kocjan A. Grypa u ciężarnych - profilaktyka i leczenie. Med Dypl 2010; 7: 21-26 (in Polish).

57. Mosby LG, Rasmussen SA, Jamieson DJ. 2009 Pandemic influenza A(H1N1) in pregnancy: a systematic review of the literature. Am J Obstet Gynecol 2011; 205: 10-18.

58. Siston AM, Rasmussen SA, Honein MA, et al. Pandemic 2009 influ-enza A(H1N1) virus illness among pregnant women in the United States. JAMA 2010; 303: 1517-1525.

59. Michaan N, Amzallag S, Laskov I, et al. Maternal and neonatal out-come of pregnant women infected with H1N1 influenza virus (Swine Flu). J Matern Fetal Neonatal Med 2012; 25: 130-132.

60. Pierce M, Kurinczuk JJ, Spark P, et al. Perinatal outcomes after maternal 2009/H1N1 infection: national cohort study. BMJ 2010; 342: d3214.

61. Yates L, Pierce M, Stephens $S$, et al. Influenza A/H1N1v in pregnancy: an investigation of the characteristics and management of affected women and the relationship to pregnancy outcomes for mother and infant. Health Technol Assess 2010; 14(34): 109-182.

62. Shi L, Tu N, Patterson PH. Maternal influenza infection is likely to alter fetal brain development indirectly: the virus is not detected in the fetus. Int J Dev Neurosci 2005; 23: 299-305.

63. Moretti ME, Bar-Oz B, Fried S. Maternal hyperthermia and the risk for neural tube defects in offspring: systematic review and metaanalysis. Epidemiology 2005; 16: 216-219.

64. CDC, H1N1 information for health care providers. 2010 [cited 11.11.2019]. Available from URL: http://www.cdc.gov/h1n1flu/clinicians/.

65. Thompson WW, Shay DK, Weintraub E, et al. Mortality associated with influenza and respiratory syncytial virus in the United States. JAMA 2003; 289; 179-186.

66. Thompson WW, Shay DK, Weintraub E. Influenza-associated hospitalizations in the United States. JAMA 2004; $292 ; 1333-1340$.

67. Barker WH, Borisute H, Cox C. A study of the impact of influenza on the functional status of frail older people. Arch Intern Med 1998; 158(6); 645-650.

68. Bandurska K. Król I, Myga-Nowak M. Interferony: między strukturą a funkcją. Postępy Hig Med Dosw 2014; 68 : $428-440$ (in Polish).

69. Effros RB. Roy Walford and the immunologic theory of aging. Immun Ageing 2005; 2: 7, doi: 10.1186/1742-4933-2-7.

70. Walford RL. The immunologic theory of aging. Munksgaard Press; 1969.

71. $\mathrm{Vu} T$, Farish S, Jenkins $\mathrm{M}$, et al. A meta-analysis of effectiveness of influenza vaccine in persons aged 65 years and over living in the community. Vaccine 2002; 20(13-14): 1831-1836.

72. Gross PA, Hermogenes AW, Sacks HS, et al. The efficacy of influenza vaccine in elderly persons. A meta-analysis and review of the literature. Ann Intern Med 1995; 123(7); 518-527.

73. Jefferson T, Di Pietrantonj C, Al-Ansary LA, et al. Vaccines for preventing influenza in the elderly. Cochrane Database Syst Rev 2010; 2 : CD004876, doi: 10.1002/14651858.

74. Darvishian M, Gefenaite G, Turner RM, et al. After adjusting for bias in meta-analysis seasonal influenza vaccine remains effective in community-dwelling elderly. J Clin Epidemiol 2014; 67(7): 734-744.

75. Kramarz P, Ciancio B, Nicoll A. Szczepienie przeciwko grypie osób w wieku podeszłym i innych grup ryzyka - sezonowe i w czasie pandemii. Przegląd dostępnych danych [cited 30.10.2018]. Available from URL: https://www.mp.pl/szczepienia/szczepieniaiszczepionki/ grupyryzyka/rozne/70671,szczepienie-przeciwko-grypie-osob-w-wieku-podeszlym-i-innych-grup-ryzyka-sezonowe-i-w-czasie-pandemii-przeglad-dostepnych-danych (in Polish). 
76. Groenwold RH, Hoes AW, Hak E. Impact of influenza vaccination on mortality risk among the elderly. Eur Respir J 2009; 34(1): 56-62.

77. Nichol KL, Margolis KL, Wouremna J, et al. Effectiveness of influenza vaccine in the elderly. Gerontology 1996; 42(5); 274-279.

78. Landry M. Diagnostic tests for influenza infection. Curr Opin Pediatr 2011; 23(1): 91-97.

79. Byambasuren S, Brydak L. Diagnostyka laboratoryjna grypy. Pediatr Med Rodz 2018; 14(3): 286-292 (in Polish).

80. Binniker M, Espy M, Irish C, et al. Direct detection of influenza A and B viruses in less than 20 minutes using a commercially available rapid PCR assay. J Clin Microbiol 2015; 53: 2353-2354.

81. Mechlers W, Kuijpers J, Sicker J. Lab-in-tube: real-time molecular point-of-care diagnostics for influenza A and B using the cobas $^{\circledR}$ Liat $^{\oplus}$ system. Med Virology 2016; 89: 1382-1386.

82. Roche product characteristics, 2018 [cited 17.12.2018]. Available from URL: https://diagnostics.roche.com/us/en/products/systems/ cobas-liat-system.html.

83. Chan K, Maldeis N, Yup A, et al. Evaluation of the Directigen Flu A+B test for rapid diagnosis of influenza virus type $A$ and $B$ infections. J Clin Microbiol 2002; 40(5): 1675-1680.

84. Petric M, Comanor L, Petti C. Role of the laboratory in diagnosis of influenza during seasonal epidemics and potential pandemics. $J$ Infect Dis 2006; 194(Suppl. 2): S98-S110.

85. Grijalva C, Poehling K, Edwards K, et al. Accuracy and interpretation of rapid influenza tests in children. Pediatrics 2007; 119(1): 1-9.

86. Iyer S, Gerber M, Pomerantz W, et al. Effect of point-of-care influenza testing on management of febrile children. Acad Emerg Med 2006; 13: 1259-1268.

87. Nitsch-Osuch A. Przydatność wykonywania szybkich testów diagnostycznych w kierunku grypy u dzieci w wieku 0-5 lat - ocean wiarygodności i implikacje kliniczne. Warszawa: Warszawski Uniwersytet Medyczny; 2013 (in Polish).

88. Nitsch-Osuch A, Kuchar E, Gołębiak I, et al. Rapid influenza diagnostic tests improve suitability of antiviral treatment in hospitalized children. Adv Exp Med Biol 2017; 968: 1-6.

89. Nitsch-Osuch A, Stefanska I, Kuchar E et al. Influence of rapid influenza test on clinical management of children younger than five with febrile respiratory tract infections. Adv Exp Med Biol 2013; 755: 237-241.

90. Jennings L, Skopnik H, Burckhardt I, et al. Effect of rapid influenza testing on clinical management of paediatric influenza. Influenza Other Resp Viruses 2009; 3(3): 91-98.

91. Nidzworski D, Siuzdak K, Niedziałkowski P, et al. A rapid-response ultrasensitive biosensor for influenza virus detection using antibody modified boron-doped diamond. Sci Rep 2017; 7, doi: 10.1038/s41598-017-15806-7.

92. Ghebrehewet S, MacPherson P, Ho A. Influenza. BMJ 2016; 355, doi: 10.1136/bmj.i6258.

93. World Health Organization. Clinical management of human infection with pandemic influenza (H1N1) 2009: revised guidance. November 2009. Available from URL: https://www.who.int/csr/resources/publications/swineflu/clinical_management_h1n1.pdf?ua=1.

94. Uyeki TM. Influenza. Ann Intern Med 2017; 167(5): 33-48.

95. Makowiec-Dyrda M, Tomasik T, Windak A, et al. Profilaktyka i leczenie grypy. Wytyczne Kolegium Lekarzy Rodzinnych w Polsce, 2016. Available from URL: https://klrwp.pl/strona/225/wytyczne-grypa-2016/pl (in Polish).

96. Mousa HA. Prevention and treatment of influenza, influenza-like illness, and common cold by herbal, complementary, and natural therapies. J Evid Based Complementary Altern Med 2017; 22(1): 166-174.

97. Viregyt-K - charakterystyka produktu leczniczego na dzień 19.11.2018. Available from URL: https://pub.rejestrymedyczne.csioz.gov. $\mathrm{pl} /$ Pobieranie.ashx?type=7065-c (in Polish).

98. Malosh RE, Martin ET, Heikkinen T, et al. Efficacy and safety of oseltamivir in children: systematic review and individual patient data meta-analysis of randomized controlled trials. Clin Infect Dis 2018; 66(10): 1492-1500.

99. Davlin SL, Blanton L, Kniss K, et al. Influenza activity - United States, 2015-16 season and composition of the 2016-17 influenza vaccine. MMWR Morb Mortal Wkly Rep 2016; 65: 567-575.

100. Garten R, Blanton L, Elal AIA, et al. Update: influenza activity in the United States during the 2017-18 season and composition of the 2018-19 influenza vaccine. MMWR Morb Mortal Wkly Rep 2018; 67(22): 634-642.

101. Dobson J, Whitley RJ, Pocock S, et al. Oseltamivir treatment for influenza in adults: a meta-analysis of randomised controlled trials. Lancet 2015; 385(9979): 1729-1737.

102. Venkatesan S, Myles PR, Leonardi-Bee J, et al. Impact of outpatient neuraminidase inhibitor treatment in patients infected with influenza A(H1N1)pdm09 at high risk of hospitalization: an individual participant data metaanalysis. Clin Infect Dis 2017; 64: 1328-1334.

103. Chaves SS, Perez A, Miller L, et al. Impact of prompt influenza antiviral treatment on extended care needs after influenza hospitalization among community - dwelling older adults. Clin Infect Dis 2015; 61(12): 1807-1814.

104. McGeer A, Green KA, Plevneshi A, et al. Antiviral therapy and outcomes of influenza requiring hospitalization in Ontario, Canada. Clin Infect Dis 2007; 45(12): 1568-1575.

105. Charakterystyka produktu leczniczego Tamiflu [cited 19.11.2018]. Available from URL: http://ec.europa.eu/health/documents/community-egister/2007/2007032821968/anx_21968_pl.pdf (in Polish).

106. Charakterystyka produktu leczniczego Ebilfumin [cited 19.11.2018]. Available from URL: https://ec.europa.eu/health/documents/ community-register/2014/20140522128580/anx_128580_pl.pdf (in Polish).

107. Charakterystyka produktu leczniczego Tamivil [cited 19.11.2019]. Available from URL: https://www.biofarm.pl/pl/produkt-opis/491 (in Polish).

108. Uyeki TM, Bernstein HH, Bradley JS, et al. Clinical Practice Guidelines by the Infectious Diseases Society of America: 2018 Update on diagnosis, treatment, chemoprophylaxis, and institutional outbreak management of seasonal influenza. Clin Infect Dis 2019; 68(6): 895-902.

109. Doll MK, Winters N, Boikos C, et al. Safety and effectiveness of neuraminidase inhibitors for influenza treatment, prophylaxis, and outbreak control: a systematic review of systematic reviews and/or metaanalyses. J Antimicrob Chemother 2017; 72(11): $2990-3007$.

110. Kumar D, Ferreira VH, Blumberg E, et al. A five-year prospective multi-center evaluation of influenza infection in transplant recipients. Clin Infect Dis 2018; 67: 1322-1329.

111. Kumar D, Michaels MG, Morris MI, et al. Outcomes from pandemic influenza A H1N1 infection in recipients of solid-organ transplants: a multicentre cohort study. Lancet Infect Dis 2010; 10: 521-526.

112. Louie JK, Jamieson DJ, Rasmussen SA. 2009 pandemic influenza A(H1N1) virus infection in postpartum women in California. Am J Obstet Gynecol 2011; 204(2): 144.e1-144.e6

113. ACOG Committee Opinion No. 753 Summary: Assessment and treatment of pregnant women with suspected or confirmed influenza. Obstet Gynecol 2018; 132: 1077-1079.

114. Beau AB, Hurault-Delarue $C$, Vial T, et al. Safety of oseltamivir during pregnancy: a comparative study using the EFEMERIS database. BJOG 2014; 121: 895-900.

115. Beigi RH, Pillai VC, Venkataramanan R, et al. Oseltamivir for the treatment of H1N1 influenza during pregnancy. Clin Pharmacol Ther 2015; 98: 403-405. 
116. Dunstan HJ, Mill AC, Stephens S, et al. Pregnancy outcome following maternal use of zanamivir or oseltamivir during the 2009 influenza A/H1N1 pandemic: a national prospective surveillance study. BJOG 2014; 121: 901-906.

117. Ehrenstein V, Kristensen NR, Monz BU, et al. Oseltamivir in pregnancy and birth outcomes. BMC Infect Dis 2018; 18: 519, doi: 10.1186/ s12879-018-3423-z.

118. Siston AM, Rasmussen SA, Honein MA, et al. Pandemic 2009 influenza A(H1N1) virus illness among pregnant women in the United States. JAMA 2010; 303: 1517-1525.

119. Muthuri SG, Venkatesan S, Myles PR, et al. Effectiveness of neuraminidase inhibitors in reducing mortality in patients admitted to hospital with influenza A H1N1pdm09 virus infection: a meta-analysis of individual participant data. Lancet Respir Med 2014; 2(5): 395-404.

120. Graner S, Svensson T, Beau AB, et al. Neuraminidase inhibitors during pregnancy and risk of adverse neonatal outcomes and congenital malformations: population based European register study. BMJ 2017; 356: j629, doi: 10.1136/bmj.j629.

121. Greer LG, Sheffield JS, Rogers VL, et al. Maternal and neonatal outcomes after antepartum treatment of influenza with antiviral medications. Obstet Gynecol 2010; 115: 711-716.

122. Saito $\mathrm{S}$, Minakami H, Nakai A, et al. Outcomes of infants exposed to oseltamivir or zanamivir in utero during pandemic (H1N1) 2009. Am J Obstet Gynecol 2013; 209: 130 e1-130 e9, doi: 10.1016/j.ajog.2013.04.007.

123. CDC. Recommendations for Obstetric Health Care Providers Related to Use of Antiviral Medications in the Treatment and Prevention of Influenza [cited 25.10.2019]. Available from URL: https://www.cdc.gov/flu/professionals/antivirals/avrec_ob.htm.

124. WHO 2014 Influenza (seasonal): fact sheet No. 211.2014 [cited 11.11.2019]. Available from URL: www.who.int/news-room/factsheet/detail/influenza-seasonal.

125. WHO recommendations on the composition of influenza virus vaccines. WHO 2019 [cited 11.11.2019]. Available from URL: www. who.int/influenza/vaccines/virus/recommendations/en.

126. GISN and laboratory. WHO [cited 11.11.2019]. Available from URL: www.who.int/influenza/areas_of_work/gisn_laboratory/en/.

127. Program Szczepień Ochronnych na rok 2019 [cited 25.10.2019]. Available from URL: https://gis.gov.pl/wp-content/uploads/2018/01/ akt.pdf (in Polish).

128. Trombetta CM, Montomoli E. Influenza immunology evaluation and correlates of protection: a focus on vaccines. Expert Rev Vaccines 2016; 15(8): 967-976

129. Coudeville L, Bailleux F, Riche B, et al. Relationship between haemaglutination-inhibiting antibody titres and clinical protection against influenza: development and application of a Bayesian rando-effect model. BCM Med Res Methodol 2010; 10: 18.

130. Canadian Immunization Guide Chapter on Influenza and Statement on Seasonal Influenza Vaccine for 2019-2020 [cited 25.10.2019]. Available from URL: https://www.canada.ca/en/public-health/services/publications/vaccines-immunization/canadian-immunization-guide-statement-seasonal-influenza-vaccine-2019-2020.html.

131. Moriarty LF, Omer SB. Infants and the seasonal influenza vaccine. A global perspective on safety, effectiveness, and alternate forms of protection. Hum Vaccin Immunother 2014; 10(9): 2721-2728.

132. Prevention and Control of Seasonal Influenza with Vaccines, 2019-20 [cited 30.11.2019]. Available from URL: https://www.cdc.gov/ flu/professionals/acip/index.htm.

133. ACIP Prevention and Control of Seasonal Influenza with Vaccines: Recommendations of the Advisory Committee on Immunization Practices - United States, 2019-20 Influenza Season [cited 11.11.2019]. Available from URL: https://www.cdc.gov/mmwr/volumes/68/rr/rr6803a1.htm.

134. Vaccines against influenza. WHO position paper November 2012 [cited 11.11.2019]. Available from URL: https://www.who.int/ wer/2012/wer8747.pdf?ua=1.

135. Walsh LK, Donelle J, Dodds L, et al. Health outcomes of young children born to mothers who received 2009 pandemic H1N1 influenza vaccination during pregnancy: retrospective cohort study. BMJ 2019; 366, doi: https://doi.org/10.1136/bmj.14151.

136. Prevention and Control of Influenza with Vaccines: Recommendations of the Advisory Committee on Immunization Practices (ACIP), 2010 [cited 11.11.2019]. Available from URL: https://www.cdc.gov/mmwr/preview/mmwrhtml/rr5908a1.htm.

Tables: 10

Figures: 2

References: 136

Received: 26.11.2019

Reviewed: 2.12.2019

Accepted: 19.12.2019

Address for correspondence:

Agnieszka Mastalerz-Migas, MD, PhD, Assoc. Prof.

Katedra i Zakład Medycyny Rodzinnej

Uniwersytet Medyczny

ul. Syrokomli 1

51-141 Wrocław

Polska

Tel.: +48 71 326-68-70

E-mail: agnieszka.migas@gmail.com 